\title{
Adoption of Embedded Open Source Software: The Case of Linux in Mobile Devices
}

\author{
By \\ René García Lozano
}

\begin{abstract}
A thesis submitted to the Faculty of Graduate Studies and Research Master of Applied Science in Technology Innovation Management
\end{abstract}

\author{
Department of Systems and Computer Engineering \\ Carleton University Ottawa, Canada
}

August, 2007

(C) Copyright René García Lozano 2007 


$\begin{array}{ll}\begin{array}{l}\text { Library and } \\ \text { Archives Canada }\end{array} & \begin{array}{l}\text { Bibliothèque et } \\ \text { Archives Canada }\end{array} \\ \begin{array}{l}\text { Published Heritage } \\ \text { Branch }\end{array} & \begin{array}{l}\text { Direction du } \\ \text { Patrimoine de l'édition }\end{array} \\ \begin{array}{l}\text { 395 Wellington Street } \\ \text { Ottawa ON K1A ON4 }\end{array} & \begin{array}{l}\text { 395, rue Wellington } \\ \text { Ottawa ON K1A ON4 } \\ \text { Canada }\end{array}\end{array}$

Your file Votre référence ISBN: 978-0-494-33646-5 Our file Notre référence ISBN: 978-0-494-33646-5

NOTICE:

The author has granted a nonexclusive license allowing Library and Archives Canada to reproduce, publish, archive, preserve, conserve, communicate to the public by telecommunication or on the Internet, loan, distribute and sell theses worldwide, for commercial or noncommercial purposes, in microform, paper, electronic and/or any other formats.

The author retains copyright ownership and moral rights in this thesis. Neither the thesis nor substantial extracts from it may be printed or otherwise reproduced without the author's permission.
AVIS:

L'auteur a accordé une licence non exclusive permettant à la Bibliothèque et Archives Canada de reproduire, publier, archiver, sauvegarder, conserver, transmettre au public par télécommunication ou par l'Internet, prêter, distribuer et vendre des thèses partout dans le monde, à des fins commerciales ou autres, sur support microforme, papier, électronique et/ou autres formats.

L'auteur conserve la propriété du droit d'auteur et des droits moraux qui protège cette thèse. $\mathrm{Ni}$ la thèse ni des extraits substantiels de celle-ci ne doivent être imprimés ou autrement reproduits sans son autorisation.
In compliance with the Canadian

Privacy Act some supporting forms may have been removed from this thesis.

While these forms may be included in the document page count, their removal does not represent any loss of content from the thesis.
Conformément à la loi canadienne sur la protection de la vie privée, quelques formulaires secondaires ont été enlevés de cette thèse.

Bien que ces formulaires aient inclus dans la pagination, il n'y aura aucun contenu manquant.

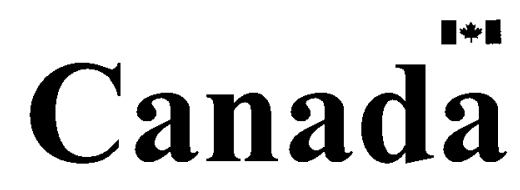




\begin{abstract}
This research examines the reasons for adoption, partnership initiation and product evolution for adoption of Linux as the embedded operating system in converged mobile devices. Data collected on 57 mobile devices and partnership agreements established between 40 mobile device manufacturers and 77 partners was used to answer four research questions that pertained to: (i) the reasons for Linux adoption; (ii) the relationship between entry rate of new devices and the entry rate of new adopters; (iii) changes on the characteristics of the devices that adopted Linux and product diversity across adoption stages; and (iv) the effect of partnerships in the adoption of Linux. The answers to these research questions are relevant at least to the chief technical officer of mobile device manufacturers, software architects of mobile device development firms, and academic researchers.
\end{abstract}




\section{ACKNOWLEDGEMENTS}

I thank God for the life He has given me and providing me strength through the hard times and moments of doubt.

I express my deepest thanks to María de los Angeles Lozano for her constant support and encouragement, and for teaching me the greatest of values through example. I love you mom. To René García Alegre for his words of wisdom, opportune comments and helpful suggestions. To Quiterie Lanusse-Cazalé for her patience and love, and for being the wonderful woman always next to me throughout every step of this challenging experience.

My gratitude to Professor Antonio Bailetti for his guidance, support and sharing of knowledge in classes and throughout the writing process of this thesis. I gratefully acknowledge all my professors and classmates from the Carleton University Technology Innovation Management program, as the experience and concepts learned from each one of them made this entire experience enlightening and worth participating in.

I am deeply indebted to Rodolfo Napoles for his advice and support. I am thankful to Miriana Dundek for her availability and long hours of proofreading to deadline. My gratitude also goes to professor Chantal Dion who always provided opportune suggestions and illuminated my path in the darkest moments. Last but not least, I would like to thank all my family members and friends who were very supportive and always available despite the distance. 


\section{TABLE OF CONTENT}

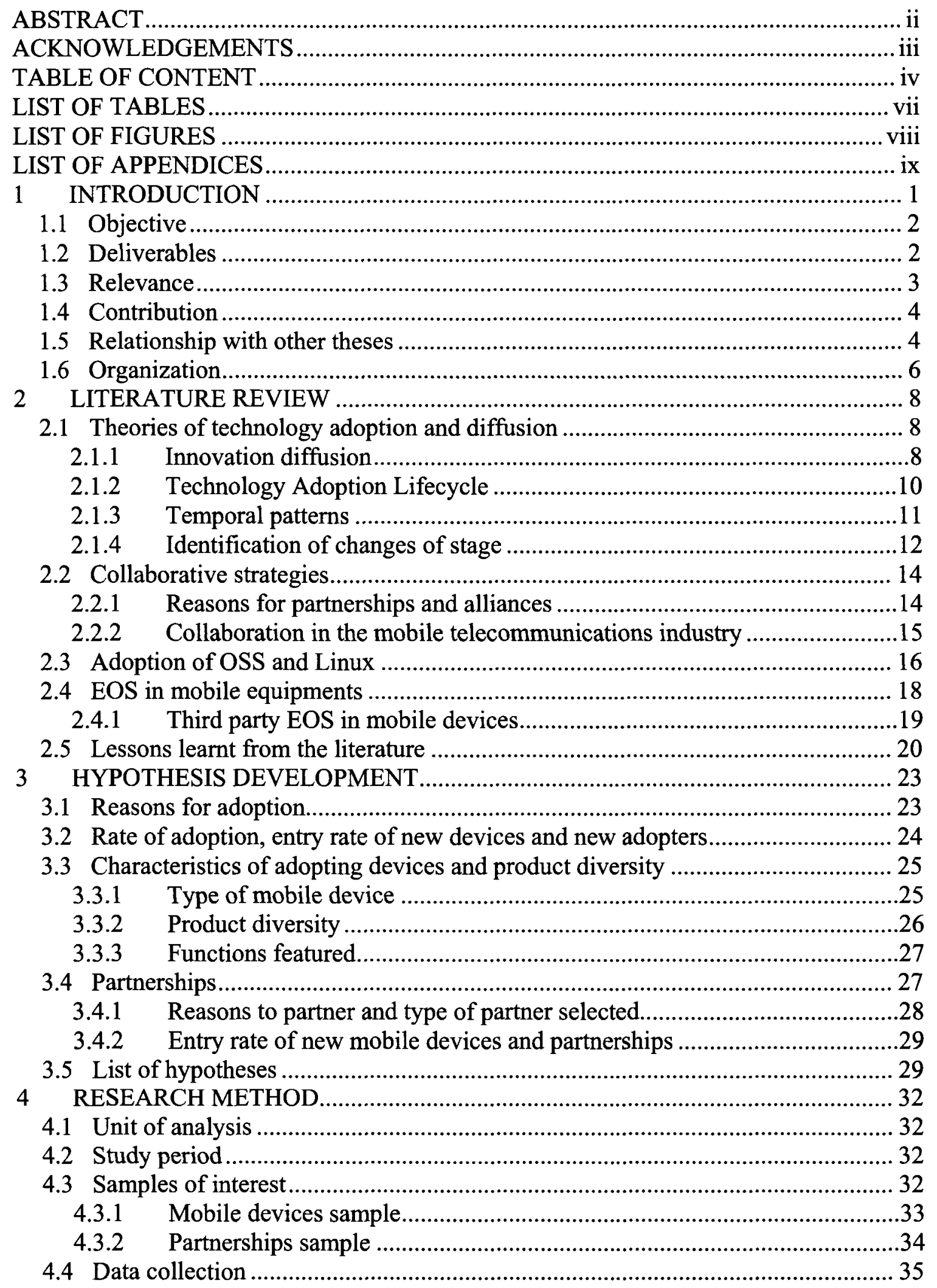




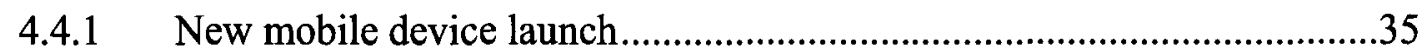

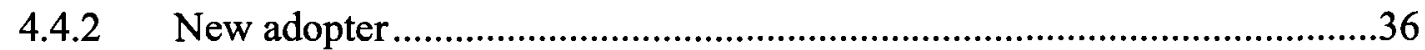

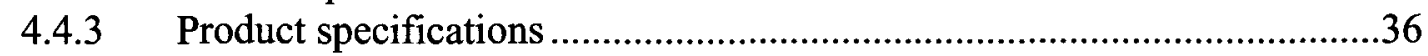

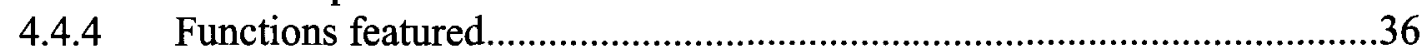

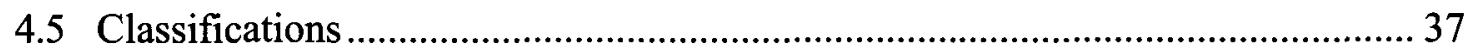

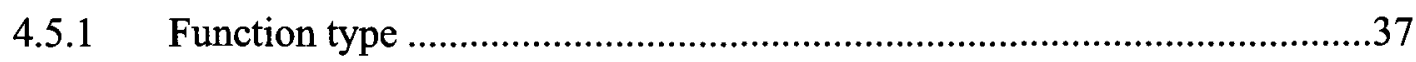

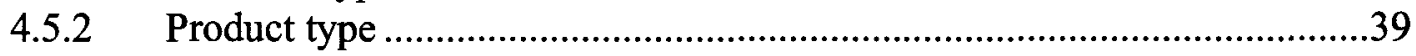

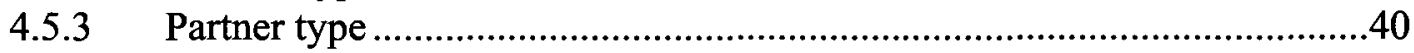

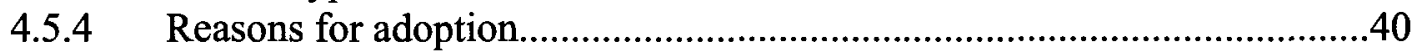

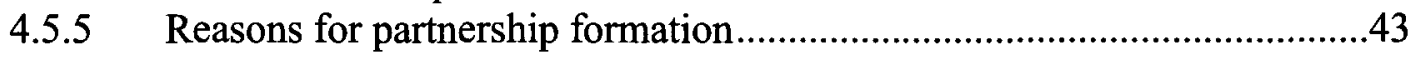

4.6 Criteria to identify adoption stage transition ..................................................... 43

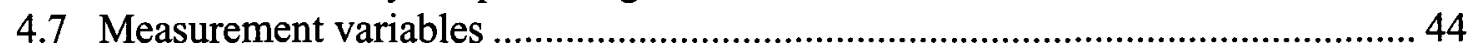

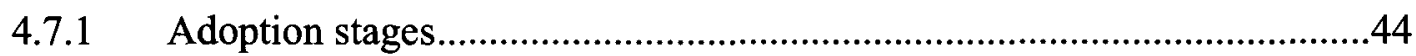

4.7.2 Entry of new mobile devices...............................................................44

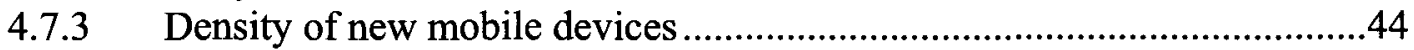

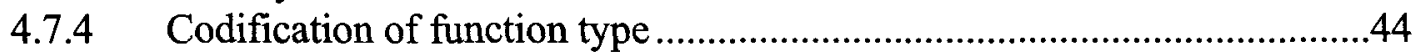

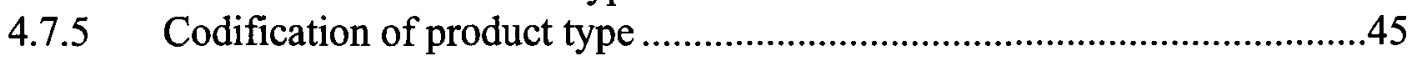

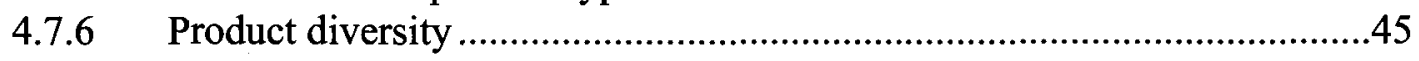

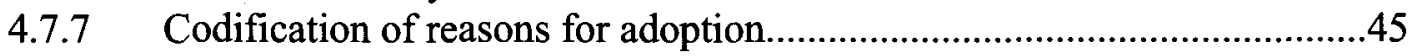

4.7.8 Number partnerships...................................................................46

4.7.9 Cumulative number of partnerships.................................................46

4.7.10 Codification of type of partner.........................................................46

4.7.11 Codification of reasons for partnership formation................................47

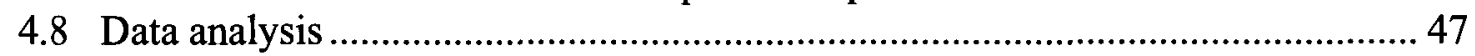

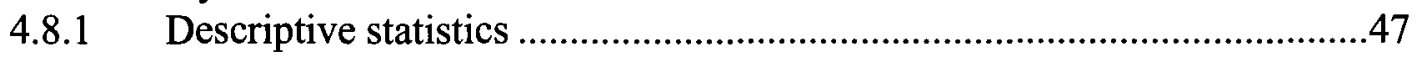

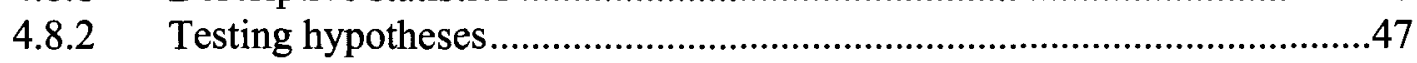

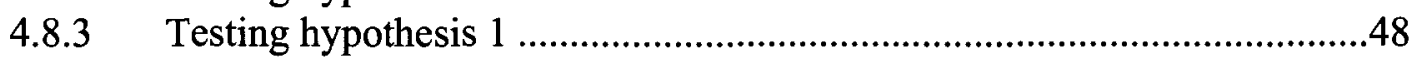

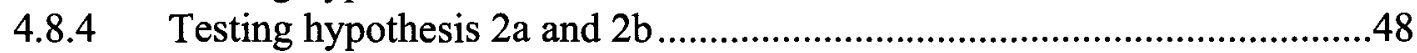

4.8.5 Testing hypothesis $3 \mathrm{a}$....................................................................49

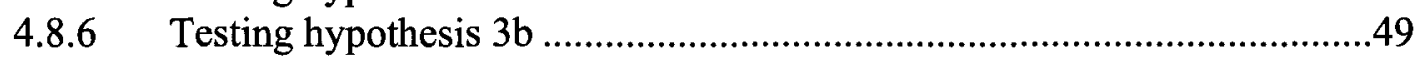

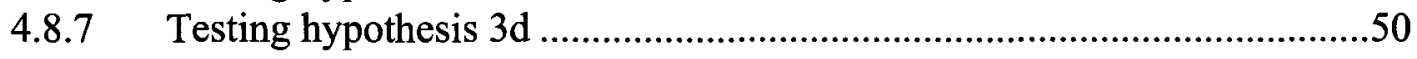

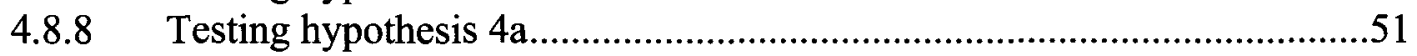

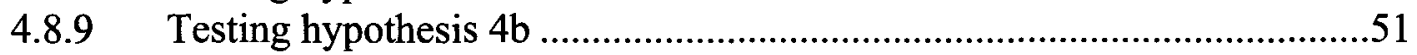

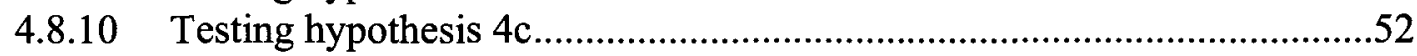

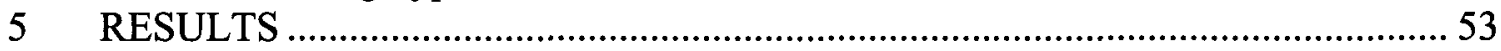

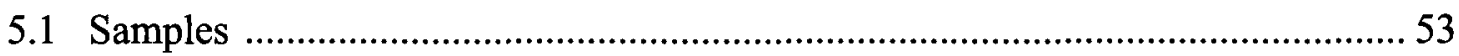

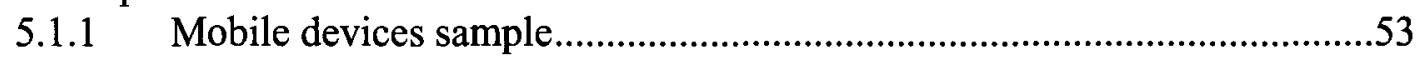

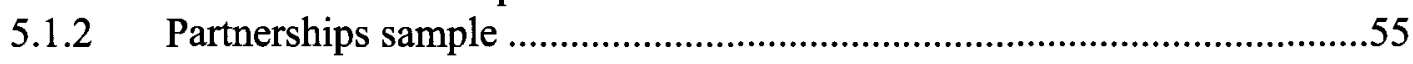

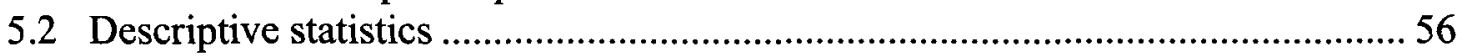

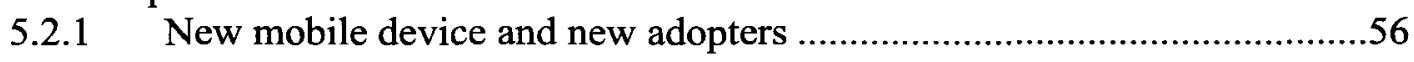

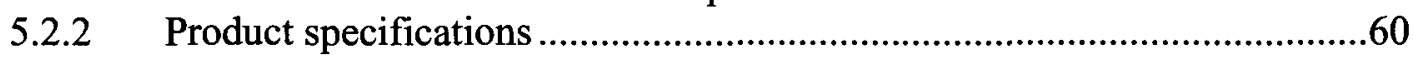

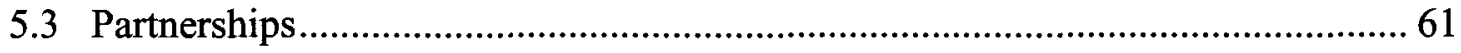

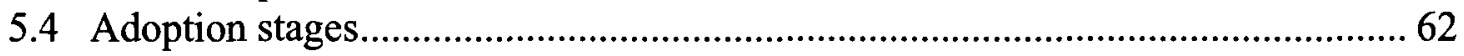

5.4.1 Identification of adoption stages.....................................................62

5.4.2 New mobile devices by stage of adoption ..........................................64

5.4.3 Product diversity by stage of adoption...............................................65 
5.4.4 Number of partnerships by stage of adoption.

5.5 Hypothesis 1: The reasons for the adoption of Linux are a function of the adoption stage

5.6 Hypothesis 2 .

5.6.1 Hypothesis $2 \mathrm{a}$ : At early stages, the entry rate of new devices is positively related to the entry rate of new adopters

5.6.2 Hypothesis 2b: At latter stages, the entry rate of new devices is negatively related to the entry rate of new adopters

5.7 Hypothesis 3.

5.7.1 Hypothesis 3a: The type of device is a function of adoption stage ...........72

5.7.2 Hypothesis 3b: At early stages, product diversity is high..........................73

5.7.3 Hypothesis 3c: At latter stages, product diversity is low .........................75

5.7.4 Hypothesis 3d: The type of functions featured by devices with Linux

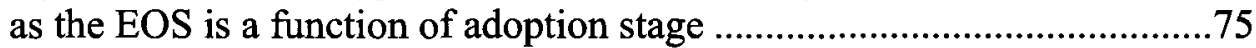

5.8 Hypothesis 4

5.8.1 Hypothesis 4a: The reasons for partnership formation are a function of adoption stage .

5.8.2 Hypothesis 4b: The type of partner is a function of adoption stage ..........80

5.8.3 Hypothesis 4c: The number of partnerships with competitors and industry consortiums are positively related to the adoption of new mobile devices

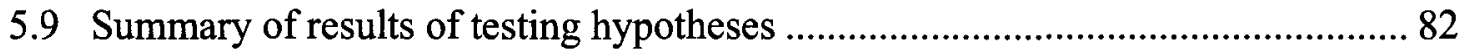

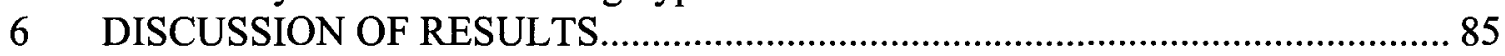

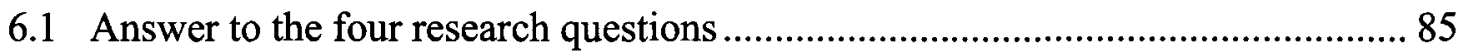

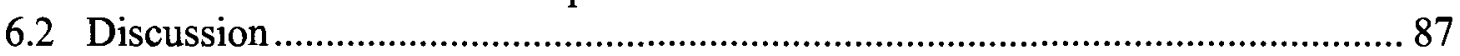

6.2.1 Reasons for adoption of Linux as the EOS in mobile devices..................87

6.2.2 Rate of adoption of Linux, entry rate of new devices and new adopters...88

6.2.3 Characteristics and product diversity of mobile devices with Linux as

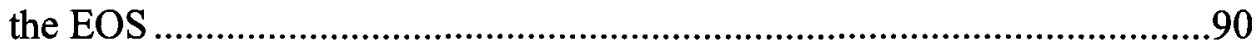

6.2.4 Partnerships and the adoption of Linux as the EOS in mobile devices .....91

7 CONCLUSION, LIMITATION AND FUTURE RESEARCH ...........................93

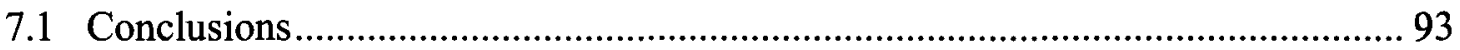

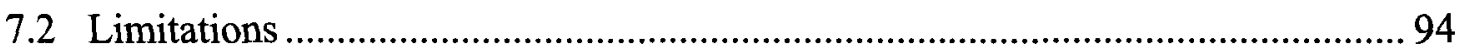

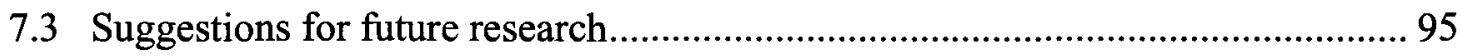

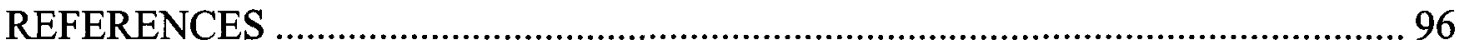




\section{LIST OF TABLES}

Table 1: Differences with previous theses ................................................................ 5

Table 2: Diffusion of innovation through characteristics of innovation......................... 10

Table 3: Keywords used to identify reasons for adoption .......................................... 42

Table 4: Number of mobile devices by type of product ..............................................54

Table 5: Descriptive statistics for the number of functions supported by type of product54

Table 6: Breakdown of partners by type....................................................................... 55

Table 7: Descriptive statistics for the five variables that pertain to mobile devices and

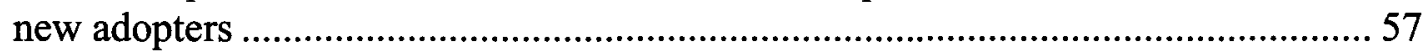

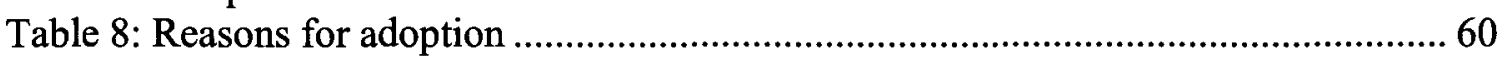

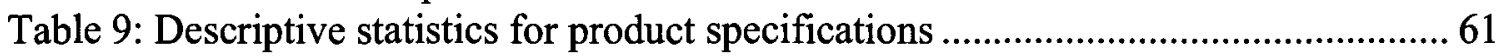

Table 10: Descriptive statistics for partners and cumulative number of partners............. 62

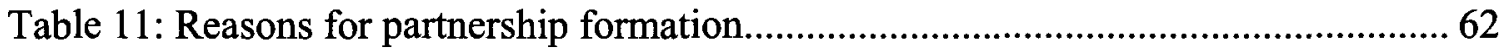

Table 12: Stage transitions based on changes in Linux kernel major revisions and GUI 63

Table 13: Number of new mobile devices by adoption stage ..........................................65 65

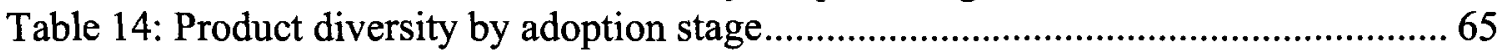

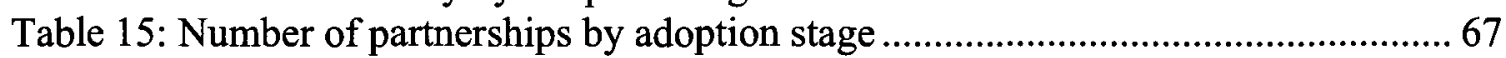

Table 16: Contingency table for reasons for adoption per adoption stage ......................67

Table 17: Chi-square test for reasons for adoption per adoption stage............................68

Table 18: Chi-square test for reasons for adoption per adoption stage...........................69 69

Table 19: Descriptive statistics for new adopters and density of adopters per adoption

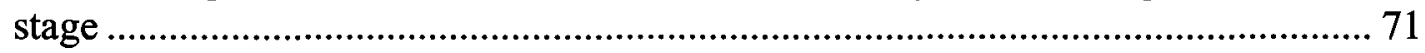

Table 20: Mann-Whitney U test comparisons for types of mobile device launched........ 73

Table 21: Descriptive statistics for product diversity per adoption stage ........................ 74

Table 22: Mann-Whitney $U$ test for comparisons for product diversity.......................... 74

Table 23: Contingency table for type of functions featured per adoption stage ............... 76

Table 24: Chi-square test for type of functions featured per adoption stage ................... 76

Table 25: Contingency table for reasons for partnership formation per adoption stage... 78

Table 26: Chi-square test for reasons for partnership formation per adoption stage....... 79

Table 27: Chi-square test for the association of type of partner .................................... 80

Table 28: Chi-square second test for the association of type of partner......................... 81

Table 29: Summary of results of testing hypotheses .................................................. 83 


\section{LIST OF FIGURES}

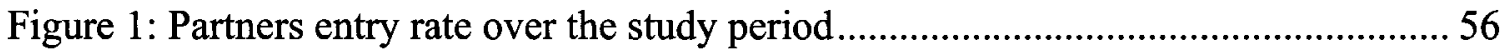

Figure 2: Entry rate of new mobile devices over time................................................ 58

Figure 3: Density of new mobile devices over time .................................................. 59

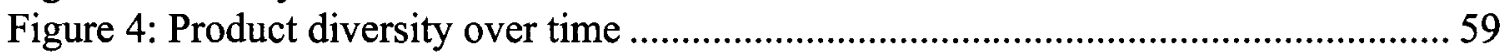

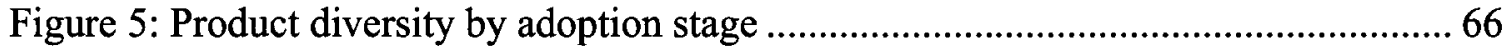




\section{LIST OF APPENDICES}

Appendix 1: Motives for alliance formation. 99

Appendix 2: Mobile devices launched with Linux as the EOS and cellular capabilities 100 Appendix 3: New adopters of mobile devices with Linux as the EOS 104

Appendix 4: Relevant partnerships during the study period 106

Appendix 5: Testing hypothesis 2 - Relation of new mobile devices entry rate and entry of new adopters entry rate per adoption stage

Appendix 6: Testing hypothesis 3a-Mann-Whitney $U$ test for type of product per adoption stage

Appendix 7: Testing hypothesis $3 \mathrm{~b}$ - Mann-Whitney $U$ test results for product diversity per adoption stage

Appendix 8: Testing hypothesis $3 \mathrm{~d}$-Descriptive statistics for type of functions featured per adoption stage

Appendix 9: Testing hypothesis $4 c-$ Relation of partnerships with competitors and industry consortia and entry of new mobile devices. 


\section{INTRODUCTION}

Mobile devices have evolved from single task oriented devices to highly complex converged mobile devices. A converged mobile device is capable of performing the functions typically featured by two or more mobile devices of different kinds. For example, a converged mobile device provides functions to assist on personal organization like a personal digital assistant (PDA), to receive and originate telephone calls like a cellular telephone, to provide geographical coordinates for location like a global position system (GPS), to reproduce music stored in digital format like an MP3 player, to take photographs and to record video like a digital camera.

Converged mobile devices require embedded operating systems. An embedded operating system (EOS) is the software that coordinates input and output operations of the different hardware elements, and manages the efficient shared use of the processor and the proper interaction with the user (Tanenbaum, 1992).

This research focuses on the adoption of Linux as the EOS in converged mobile devices with cellular capabilities. The development of reduced versions of the Linux kernel has enabled it to be used as the embedded system in converged mobile devices with connection to cellular networks. 


\section{$1.1 \quad$ Objective}

The objective of this research is to answer four questions relevant to the adoption of Linux as the EOS for mobile devices. These four questions are:

(i) What are the reasons to adopt Linux?

(ii) What is the relationship between the entry rate of new converged mobile devices with Linux as the EOS and the entry rate of new adopters over time?

(iii) How do the characteristics of the devices that adopted Linux as the EOS and product diversity change across adoption stages?

(iv) How do partnerships affect the adoption of Linux?

To answer these four questions, a set of four testable hypotheses was developed. Each hypothesis is related to a research question.

\subsection{Deliverables}

The deliverables of this research are:

(i) Descriptive statistics about the adoption of Linux as the EOS in converged mobile devices and insightful observations about the data collected

(ii) Results of testing four hypotheses

(iii) Predictions about what is going to happen in the competition period of innovation 


\subsection{Relevance}

This research is relevant to at least three audiences. First, the outcomes of this research are relevant to the chief technical officer (CTO) of mobile device manufacturers. The CTO defines the direction of a company in terms of technology for the long term. CTOs will know that the technology lifecycle has not reached the competition stage because it was found that a positive relationship exists between the entry rate of new converged mobile devices with Linux as the EOS and the entry rate of new adopters. In addition, CTOs will learn that partnerships with competitors and industry consortia are critical to the adoption of new converged mobile devices. These insights may be useful to CTOs when deciding whether or not to adopt Linux as the EOS for converged mobile devices.

Second, this study is relevant to researchers because it proposes a method for classifying converged mobile devices. The classification method is based on user requirements. The method allows observations of submarkets for further evaluation of the rapidly growing market for converged mobile devices.

Third, the observations of this research are relevant to software architects of mobile device original design manufacturers (ODMs). Software architects might benefit from knowing that the adoption of Linux as the EOS is increasing. 


\subsection{Contribution}

This research makes three contributions. First, it suggests that the process of adoption of embedded Linux as the EOS for converged mobile devices is still at the legitimization stage.

Second, the examination of adoption of Linux at the legitimization stage allows predictions for the competition stage.

Third, this research uses industry knowledge to contribute a classification method for converged mobile devices based on user requirements.

\subsection{Relationship with other theses}

Peng (2004), Napoles (2005) and Ali (2005) examined adoption processes of technology innovations. This thesis builds on lessons learned from these three theses and follows some of the methods used in these studies.

Table 1 summarizes the differences between this thesis and the theses completed by Peng (2004), Napoles (2005) and Ali (2005). 
Table 1: Differences with previous theses

\begin{tabular}{|c|c|c|c|c|}
\hline Dimension & $\begin{array}{l}\text { Garcia Lozano } \\
(2007)\end{array}$ & Peng (2004) & Napoles (2005) & Ali (2005) \\
\hline $\begin{array}{l}\text { Technological } \\
\text { innovation } \\
\text { adopted }\end{array}$ & $\begin{array}{l}\text { Embedded } \\
\text { Linux }\end{array}$ & Linux & $\begin{array}{l}\text { Unified } \\
\text { modeling } \\
\text { language } \\
\text { (UML) }\end{array}$ & $\begin{array}{l}\text { Voice over } \\
\text { internet } \\
\text { protocol (VoIP) }\end{array}$ \\
\hline $\begin{array}{l}\text { Unit of } \\
\text { analysis }\end{array}$ & $\begin{array}{l}\text { Converged } \\
\text { mobile devices }\end{array}$ & $\begin{array}{l}\text { Commercial } \\
\text { suppliers of } \\
\text { Linux products }\end{array}$ & $\begin{array}{l}\text { UML-based } \\
\text { development } \\
\text { tools buyers } \\
\text { and suppliers }\end{array}$ & $\begin{array}{l}\text { VolP service } \\
\text { operators }\end{array}$ \\
\hline $\begin{array}{l}\text { Market } \\
\text { segment }\end{array}$ & $\begin{array}{l}\text { Cellular capable } \\
\text { devices }\end{array}$ & $\begin{array}{l}\text { All kinds of } \\
\text { suppliers }\end{array}$ & $\begin{array}{l}\text { All kinds of } \\
\text { buyers and } \\
\text { suppliers }\end{array}$ & $\begin{array}{l}\text { North } \\
\text { American } \\
\text { operators }\end{array}$ \\
\hline $\begin{array}{l}\text { Partnerships } \\
\text { established } \\
\text { by: }\end{array}$ & $\begin{array}{l}\text { All known } \\
\text { mobile device } \\
\text { manufacturers } \\
\text { that adopted } \\
\text { Linux as the } \\
\text { EOS }\end{array}$ & $\begin{array}{l}\text { North } \\
\text { American and } \\
\text { European Linux } \\
\text { distributors }\end{array}$ & $\mathrm{N} / \mathrm{A}$ & $\begin{array}{l}\text { Four North } \\
\text { American } \\
\text { operators }\end{array}$ \\
\hline $\begin{array}{l}\text { Determinant } \\
\text { for adoption } \\
\text { stage } \\
\text { transition }\end{array}$ & $\begin{array}{l}\text { Higher Linux } \\
\text { kernel revision } \\
\text { or higher GUI } \\
\text { version }\end{array}$ & $\begin{array}{l}\text { New type of } \\
\text { application or } \\
\text { new running } \\
\text { environment }\end{array}$ & $\begin{array}{l}\text { New product } \\
\text { type }\end{array}$ & $\begin{array}{l}\text { New class of } \\
\text { service }\end{array}$ \\
\hline
\end{tabular}

First, the present research differs from those by Peng (2004) and Napoles (2005) in that it focuses on the adoption of Linux as the EOS within a specific market segment. This research examines the cellular capable converged mobile device market. The research 
results are specific to the selected market. In contrast, Peng's research examined adopters of Linux across various markets and Napoles considered all sorts of buyers and suppliers of UML-based tools.

Second, this research is different to those by Peng (2004) and Ali (2005) in that it examines all known partnerships established by converged mobile device manufacturers that adopted Linux as the EOS. Both Peng's and Ali's research focused on a sample of suppliers. Peng (2004) focused on partnerships established by a selected group of North American and European Linux distributors. Ali (2005) examined the partnerships established by four selected North American service operators.

Third, this research used technological improvements as determinant for adoption stage transitions. The determinant factor was the adoption of a newer major revision of the Linux kernel or a newer version of the graphic user interface (GUI). Peng (2004), Ali (2005) and Napoles (2005) used data related to adopters to identify stage transitions. Peng (2004) used suppliers' data on type of application and running environment. Napoles (2005) used suppliers' and buyers' data on product types. Ali (2005) used service operators' data on class of service.

\subsection{Organization}

The thesis is organized into seven chapters. Chapter 1 is the introduction. Chapter 2 provides a review of the relevant literature. Chapter 3 develops the hypotheses that were tested. Chapter 4 describes the research method. Chapter 5 presents the results obtained 
from testing the hypotheses. Chapter 6 discusses the results. And chapter 7 presents the conclusions, identifies the limitations of this study, and describes opportunities for future research. 


\section{LITERATURE REVIEW}

This chapter presents a review of the literature relevant to the adoption of Linux as the EOS in mobile devices. Section 2.1 examines the theories of technology adoption and diffusion. Section 2.2 reviews the existing literature on collaborative strategies, partnership and alliances, and collaboration in the mobile telecommunications industry. Section 2.3 reviews the literature on adoption of OSS and Linux. Section 2.4 introduces research efforts around EOS for mobile equipments. Finally, section 2.5 presents a summary of the lessons learnt from the literature.

\subsection{Theories of technology adoption and diffusion}

Among the existing literature dealing with technology adoption and diffusion two theoretical frameworks have received the most attention. The first is the innovation diffusion theory by Rogers (1983). The second is the Technology Adoption Lifecycle (TALC) framework by Moore (1991). In addition, research efforts have studied temporal patterns of technology adoption by extending the density-dependence model to explain changes on the lifecycle over time. Finally, some recent research efforts have been made to identify the stages of adoption of unfinished adoption lifecycles. The following sections present a summary of the key insights of all these approaches.

\subsubsection{Innovation diffusion}

Rogers (1993) introduced a theoretical framework to study innovation diffusion. Based on intensive observations of diffusion of technological innovation in several fields, this 
framework proposes a classification of adopters based on the point of time at which they adopt. According to this framework, entities embracing a particular new technological advancement can be placed in one of five categories: (i) innovators; (ii) early adopters; (iii) early majority; (iv) late majority; and (v) laggards.

Moreover, this theoretical framework describes important differences existing between the types of adopters, which extend beyond the point of adoption alone. These distinctions are presented in terms of the characteristics of adopters and their motivations to adopt a technological innovation. The latter is highlighted as one of the determinant factors that ultimately define the decision of adoption.

In addition, another important factor that determines the adoption decision is the perceived characteristics of an innovation from the particular perspective of the potential adopter. More specifically, Rogers (1983) concluded that the most important characteristics of an innovation, as perceived by adopters, and which are positively related to the innovation's rate of adoption are: (i) relative advantage; (ii) compatibility; (iii) reduced complexity; (iv) triability; and (v) observability.

Table 2 presents the description of the characteristics of innovation identified as most relevant to the diffusion of innovation. 
Table 2: Diffusion of innovation through characteristics of innovation

\begin{tabular}{|l|l|}
\hline Characteristic & Description \\
\hline Relative advantage & $\begin{array}{l}\text { Degree to which an innovation is perceived as being better } \\
\text { than the idea it supersedes. It may be measured in economic } \\
\text { terms, social-prestige factors, convenience and satisfaction }\end{array}$ \\
\hline Compatibility & $\begin{array}{l}\text { Degree to which an innovation is perceived as being } \\
\text { consistent with existing values, past experiences and needs } \\
\text { of potential adopters }\end{array}$ \\
\hline Less complexity & $\begin{array}{l}\text { Degree to which an innovation is perceived as less difficult } \\
\text { to understand and use }\end{array}$ \\
\hline Triability & $\begin{array}{l}\text { Degree to which an innovation may be experimented with a } \\
\text { limited basis }\end{array}$ \\
\hline Observability & $\begin{array}{l}\text { Degree to which the results of an innovation are visible to } \\
\text { others }\end{array}$ \\
\hline
\end{tabular}

Source: Rogers 1983

\subsubsection{Technology Adoption Lifecycle}

The Technology Adoption Lifecycle (TALC) framework was introduced by Moore (1991) based on the key findings of the diffusion of innovation theory (Rogers 1983). Building on the classification of adopters, TALC further develops on the particulars of the adoption of high-tech over time thereby presenting a revision of the adoption lifecycle.

The TALC revised version draws important distinctions between the characteristics of adopters at each stage of the adoption cycle. This framework introduces the concept of gaps between consecutive stages of adoption. Moreover, a great importance is given to 
the gap between early adopters and early majority, which is described as the "chasm" (Moore 1991).

The "chasm" marks the boundaries between the early market and the mainstream hightech market. Moore (1991) describes how crossing this gap is one of the main determinants that defines the emergence of a mainstream market for a high-tech innovation. Furthermore, the framework identifies that there are important differences between the motivations of adopters of the early market, on one side of the "chasm", and early majority adopters on the other.

\subsubsection{Temporal patterns}

Temporal patterns provide arguments to understand the evolution of technology innovation adoption processes. Among others, these include the evaluation of observations about the characteristics and diversity of the product adopted, and the entry rate of adopters and the density of the resulting population. In this research field, two research approaches have been applied in order to provide relevant insights from temporal patterns related to the adoption of technological innovation.

First, Debackere and Clarysse (1998) present a study on the relationship between the population of a network structure and the entry rate. By using the density-dependence model, they found that the entry patterns of a network structure are constrained by the population density of the network. 
Second, a technology diffusion study performed by Geroski (2000) provides a model to further explain the S-curve of the diffusion process. The research describes the characteristics of legitimization and competition periods. Whereas during the legitimization period there is a dependence on the number of individuals it takes to gain acceptance or validity, during the competition period the population density limits the number of individuals that can survive in the market.

Furthermore, the study describes that at first, during the legitimization period, the adopter's expressed interest towards a technological innovation comes in a variety of forms. The choices made by adopters which occur during the legitimization period have an extremely powerful effect on the path of diffusion. After that, when a variant becomes established in the market, competition takes place with whatever variant is chosen. The study concludes that the balance between the forces of legitimization and competition limits the diffusion of a new technological advance (Geroski, 2000).

These two approaches use temporary patterns to further develop explanations around the diffusion of technology innovation.

\subsubsection{Identification of changes of stage}

Building on the theories of adoption and diffusion, a thesis research of the masters in telecommunications technology management (TTM) program by Peng (2004) provides a method to identify adoption stages of an ongoing adoption lifecycle. The method uses changes in diversity of the new products introduced to identify adoption stage transitions. 
Following Peng's method, subsequent TTM theses by Napoles (2005) and Ali (2005) performed research works to study different aspects of unfinished adoption lifecycles.

First, Peng (2004) used application types and running environments data to mark stage changes on the adoption cycle of Linux products by supplier companies. The research suggests that there is a relationship between size of firms and adoption stages. In addition, the study findings describe that during the legitimization process the number of partnerships is positively related to the entry rate. However, no association was found between the type of product and adoption stages, and nor was there an association between partnerships and entry rate during the competition process at latter stages. Finally the research concludes that numerous changes in product diversity occur during the legitimization period, whereas the competition period is characterized by low changes in product diversity.

Subsequent research by Napoles (2005) observed product type information as being the determinant factor for adoption stage transition of unified modeling language (UML) based applications tools. The research findings suggest that there is an association between the adoption stages and the supplier size. At early stages suppliers were much larger than those of latter stages. In addition, this research concludes that adoption stages are related to the product category and to the suppliers' and buyers' reasons for adoption.

Finally, Ali (2005) used class of service data as determinant for stage change on the adoption process of voice over IP (VoIP) by service providers. The results of this 
research suggest that there is no association between the size of the adopting firms and the adoption stages. However, the type of services adopted and product diversity are related to the adoption stage. Moreover, the study concludes that the type of partner selected is different across adoption stages and the number of partnerships is greater at latter stages than at early stages.

The method proposed on the TTM master's thesis by Peng (2004) has proven to be effective in identifying adoption stage changes. Further research works by Napoles (2005) and Ali (2005) showed that insightful knowledge about technology innovation adoption can be gained through a careful selection of events that mark the transition among adoption stages. Moreover, the contrasting results of these three works suggest that significant differences can be found among different technological innovations' adoption life cycles and for different groups of adopters.

\subsection{Collaborative strategies}

This section presents a review of the literature pertaining to partnerships and alliances as well as the research efforts made around collaboration in the mobile telecommunications industry.

\subsubsection{Reasons for partnerships and alliances}

Literature about the reasons to participate in partnerships and alliances includes a considerably long list of research efforts. Some of the streams covered by researchers 
exploring this field include resource dependency (Pfeffer and Nowak 1976), transaction cost economics (Williamson, 1991; Hennart, 1988, 1991), organizational learning (Grant, 1996; Hamel, 1991; Khanna et al., 1998; Mowery et al., 1996), strategic networks (Porter 1983), social networks (Gulati 1995), and institutional theory (DiMaggio and Powell, 1983). These different views help provide a better understanding of the motives behind partnerships and alliances.

\subsubsection{Collaboration in the mobile telecommunications industry}

The mobile telecommunications industry, well-known for its ever rapidly evolving characteristic, urges agile collaborative moves by the companies that comprise this technological landscape. Research efforts have looked closely at collaboration within this industry. An example of these efforts is a study made on the impact of alliances in the standardization of Bluetooth (Keil, 2002). Findings show that the large combined market share represented by the companies behind the creation of Bluetooth strongly influenced its emergence as a standard. Bluetooth is not an isolated case on the force of alliances towards the establishments of standards.

Another example is the research conducted on the role of cooperation and competition in setting standards for operating systems in mobile devices (Oshri and Weeber, 2006). This study observed the characteristics of the standard-setting actions taken by the collaborative alliance of industry leaders involved in the Symbian consortium. These actions were further compared to those taken by Microsoft, Palm and Sun in relation to their own operating systems. The findings include the description of a hybrid mode of 
actions used by standard setters, a combined form of collaborative and competitive modes defined as "co-opetition" (Oshri and Weeber, 2006).

Furthermore, research surrounding the industry dynamics in the case of Vodafone Groups (Dodourova, 2003) provides a classification of the motives for alliance in the mobile telecommunications industry. The findings of this research reveal that product-related, technology-related and market-related motives are decidedly the most important motives for partnership. Appendix 1 presents a table with the classification of motives for partnership, as identified through the Vodafone Groups study.

\subsection{Adoption of OSS and Linux}

The adoption of OSS by commercial for-profit firms has particularly attracted the attention of researchers and scholars during the past couple of years. The related literature provides arguments to conclude that the two main factors for the success of OSS are the motivation of developers to contribute to OSS projects (Franke and von Hippel, 2003; Lerner and Tirole, 2002; Markus et al, 2000; von Hippel and von Krogh 2003) and its utility as perceived by the user (Stewart et al. 2005). Therefore, the ways companies perceive utility in open software is an important factor in helping to determine and understand the adoption of OSS.

Previous research on the adoption of OSS has been mainly focused on the server level platform. At this level, it has been observed that factors like switching costs and the current degree of satisfaction with existing commercial platforms versus no guarantee of 
satisfaction with a different platform are some of the main barriers for adoption (Chau and Tam, 1997). Nevertheless, a later comparative study on operating systems found that in recent years the open license characteristics of Apple's Mac OS X and GNU/Linux have helped them gain stronger ground over Microsoft Windows (Välimäki and Oksamen, 2005).

In addition, a group of research works have covered the adoption of Linux in particular. Some of the key findings suggest that small companies tend to adopt Linux earlier with larger firms following, and that they may both coexist in a competitive market (Peng, 2004). Moreover, the willingness and ability of organizations to adopt Linux depend on how they value relative advantage, compatibility and complexity of the offering (Dedrick and West, 2004).

Furthermore, another recent research study was targeted to developers of embedded Linux (Henkel, 2006). The objective was to observe the share of firm developed code revealed as a result of using embedded Linux, and how it relates to firm size, policies, need for complementary assets and the reasons for revealing code. Some of the findings included that firms reveal code in proportion to their need of obtaining external development support and for cost/benefit considerations. The study concluded that smaller firms reveal more code which is likely expected to benefit from the external resources support that open source offers. 
However, no evidence was found of research conducted on the adoption of embedded Linux which encompasses the mechanics applied within a particular industry segment despite the fact that the industry demands a closer observation of the adoption phenomenon. Hence, the particular implications of the structure and common practices related to the mobile telecommunications industry offer an excellent opportunity to evaluate the impact they might cause on the adoption process of embedded Linux.

\subsection{EOS in mobile equipments}

EOS origins bring us back in history to as early as the creation of computers. An EOS is the portion of code that runs on kernel mode and hides the complexities of hardware to provide the user with a convenient set of instructions to interact with the system (Tanenbaum, 1992). This research deals specifically with EOS for mobile devices to allow the interaction between the user and hardware components. The maximum number of lines of code in mobile equipment is constrained by the capacity of the embedded processor.

In the earlier years of cellular devices, processors allowed a very restricted number of embedded lines of code. Therefore, the EOS in these mobile device handsets provided support to very basic functions that included authentication information with the system, dialling information, regular communication with the cellular system for the identification of location and change of frequency, so as to allow for hand-over from one base station to another (Garrard 1998). In most of the cases the EOS were developed by the equipment manufacturer or custom-developed by software companies. 
In recent years, mobile device equipment manufacturers have incorporated many more functions to the handset terminals than those of the early days. Advances in semiconductor technology have provided exponentially increased capacity in a much reduced physical space. This size reduction, combined with increased processing capacities, has driven equipment manufacturers to include more complex and diversified functions in mobile devices.

\subsubsection{Third party EOS in mobile devices}

With the increasing demand for more complex mobile devices, equipment manufacturers are gradually abandoning the old practice of developing in-house system code lines for the interaction of mobile equipments with the user. As media players, cameras and other personal computing options become more pervasive on the cellular market, handset manufacturers have adopted third party developed EOS, rather than losing concentration on their core market. The most remarkable examples of third party EOS in cellular mobile devices are Symbian OS (Symbian, 2007), Microsoft Windows Mobile (Microsoft Corporation, 2007) and embedded Linux.

Within the scope of the mobile device industry, a recent study observed the role of companies and coalitions of industry players and their influence towards the standardization setting of EOS of their own creation. It observed the cases of Symbian, Microsoft, PalmSource and Sun behind Symbian OS, Windows Mobile, Palm OS, and J2ME respectively (Oshri and Weeber, 2006). However, the form of the efforts made by 
individual companies or alliances of industry players and their role towards the standardization of Linux still remains unclear.

\subsection{Lessons learnt from the literature}

\section{Lack of studies focused on an industry segment}

Research on the adoption of embedded Linux within the scope of a particular industry segment is lacking.

\section{Lack of a classification method}

A method to classify converged mobile devices does not exist.

\section{Most important characteristics related to the rate of adoption of an innovation}

Relative advantage, compatibility, less complexity, triability and observability as perceived by potential adopters are the most important characteristics positively related to the rate of adoption of an innovation. The adoption of open source software depends on the perceived relative advantage, compatibility and complexity of the offering.

\section{Classification of new technology adopters}

New technology adopters can be classified according to the point of time at which they adopt. Moreover, there are important differences in the characteristics and motivations of adopters at earlier stages and adopters at latter stages. It is only when a high-tech innovation meets the requirement of the latter, that the mainstream market can emerge. 


\section{Forces of legitimization and competition}

The diffusion of an innovation is limited by the forces of legitimization and competition. During the legitimization period, innovation gains acceptance and validity through the increment on the number of adopters. As a result, the density of the network is positively related to the number of new entrants to the network. In addition, in the legitimization period adopters chose to use the technological innovation in a variety of forms. In contrast, during the competition period the density of the population is negatively related to the number of new entrants to the network. Moreover, the choice in the competition period centers on the variant that becomes established in the market.

\section{Identification of adoption stages}

An empirical method can be used to identify the stages of adoption for an incomplete adoption lifecycle.

\section{Partnerships in the mobile telecommunications industry}

In the mobile telecommunications industry, partnerships and alliances influence the emergence of industry standards. Partners and allies can also be direct competitors. 


\section{Motives for partnership}

Dodourova (2000) proposed a classification for the motives of partnership in the mobile telecommunications industry. The most relevant motives for partnership can be categorized as product-related, technology-related, and market-related. 


\section{HYPOTHESIS DEVELOPMENT}

This chapter develops the hypotheses tested to find the answer to the four research questions. Section 3.1 develops the hypothesis used to identify the reasons for the adoption of Linux as the EOS. Section 3.2, develops the hypothesis concerning the rate of adoption of Linux by converged mobile devices. Section 3.3 develops the hypothesis used to assess the characteristics and the product diversity of the devices adopted over time. Section 3.4 develops the hypothesis to examine how partnerships affect the adoption process. Finally, section 3.5 provides a list of hypotheses developed for this research.

\subsection{Reasons for adoption}

The first research question is: what are the reasons for adoption of Linux as the EOS for converged mobile devices? Dedrick and West (2004) found that the most important reasons to adopt Linux as the server operating platform were relative advantage, compatibility and reduced complexity. However, the motivations for adopting innovation are different over time (Rogers 1983; Moore 1991; Napoles 2005). It is expected that the reasons for the adoption of Linux as the EOS for converged mobile devices will be different across adoption stages. Therefore,

Hypothesis 1: The reasons for the adoption of Linux are a function of the adoption stage 


\subsection{Rate of adoption, entry rate of new devices and new adopters}

The second research question is: what is the relationship between the entry rate of new devices with Linux as the EOS and the entry rate of new adopters over time? Rate of adoption is defined as the relative speed with which a new technology is embraced by a group of adopters (Rogers, 1983). According to the density-dependence model, the network's population density has an effect on entry rate (Debackere et al., 1998). The reasoning is that during a legitimization period, the density of new devices provides validity and acceptance to the innovation, being positively related to the entry rate of new adopters. In contrast, during a competition period the density of new devices in the network reaches a critical level and becomes negatively related to the entrance of new adopters.

Peng (2004) examined the relationship between the cumulative number of Linux suppliers and the entry rate of new suppliers. He concluded that the entry rate of established firms as Linux suppliers increased at early stages and then slowed down during the late stages. Napoles (2005) made the distinction between the entry rate of new buyers and new suppliers of UML-based development tools. He concluded that new buyers' entry rate followed a bell shape distribution, whereas new suppliers' entry rate did not. Finally, Ali's (2005) research concluded that the entry rate of new VoIP service operators followed a bell shape distribution.

It is expected that in the case of adoption of embedded Linux as the EOS for converged mobile devices the entry rate of new devices at early stages is positively related to the 
entry rate of new adopters. It is expected that at latter stages the entry rate of new devices is negatively related to the entry rate of new adopters. Therefore:

Hypothesis 2a: At early stages, the entry rate of new devices is positively related to the entry rate of new adopters

Hypothesis 2b: At latter stages, the entry rate of new devices is negatively related to the entry rate of new adopters

\subsection{Characteristics of adopting devices and product diversity}

The third question that this research intends to answer is: how do the characteristics of the devices that adopt Linux as the EOS and product diversity change across adoption stages? The observations of a repeated series of events over time during the adoption of new technology help provide an understanding of the evolution and direction of the related market. Three characteristics of Linux converged mobile devices were observed: (i) type of mobile device; (ii) product diversity; and (iii) type of functions featured.

\subsubsection{Type of mobile device}

The type of product offered during an innovation adoption process is likely to change over time. Geroski (2000) sustains that diffusion of a new technology is about matching a wide range of different users' needs. Therefore, manufacturing companies must constantly modify their product offerings in order to provide fulfillment to changing 
users' requirements. Previous studies have examined the relationship between type of product introduced and the stage of adoption. Napoles (2005) and Ali (2005) found a significant association between the adoption stage and the type of new products introduced. However, the research by Peng (2004) found no significant association between stage of adoption and type of Linux product offered by adopting supplier firms.

To better understand the evolution of converged mobile devices, it is relevant to examine the type of products offered during the adoption process. It is expected that the type of converged mobile devices launched change over time. Therefore,

Hypothesis 3a: The type of device is a function of adoption stage

\subsubsection{Product diversity}

Geroski (2000) characterizes the legitimization period by variations of the form chosen by adopters. During the competition period, the variations stall around the form that has become established in the market. Peng (2004), Napoles (2005) and Ali (2005) observed such changing patterns in product diversity. The three used changes in product diversity to identify the legitimization and competition periods.

It is expected that high variations on product diversity occur at early stages and low product diversity at latter stages. Therefore,

Hypothesis 3b: At early stages, product diversity is high 
Hypothesis 3c: At latter stages, product diversity is low

\subsubsection{Functions featured}

Converged mobile devices are characterized by featuring functions of several types of mobile devices. EOS allows equipment manufacturers to include an increasing number of new functions of different types to their converged mobile device offering. Geroski (2000) emphasized the effect that choices made at the legitimization process have on the path of diffusion. It is expected that the type of functions featured changes across stages of adoption. Therefore,

Hypothesis 3d: The type of functions featured by devices with Linux as the EOS is a function of adoption stage

\subsection{Partnerships}

Partnerships and alliances in the mobile telecommunication industry have proven to be influential in the emergence of industry standards. For instance, the group of companies which developed Bluetooth used partnerships to propel its emergence as the industry standard (Keil, 2002). However, in the case of non-proprietary components, such as Linux, the role of partnerships remains unclear. This research examines: (i) what the motivations for partnership formation are; (ii) the relationship between the type of partner 
selected and adoption stage; and (iii) the effect of partnerships on the entry rate of new mobile devices.

\subsubsection{Reasons to partner and type of partner selected}

Ali (2005) found that during the first and the last stage of adoption, the motives for partnership were mainly product or service related. During the second and third stages motives for partnerships were mostly technology related. Then during the fourth stage of adoption the motives were strategic or market related and product or service related.

Peng (2004) did not find an association between the reasons for partnership formation and adoption stage. Both Peng (2004) and Ali (2004) surmised that an association between the type of partner selected and the motives for partnership formation existed. However, neither one tested the relationship.

It is expected that the reasons for partnership formation and the type of partner selected differ across adoption stages. Therefore,

Hypothesis 4a: The reasons for partnership formation are a function of adoption stage

Hypothesis 4b: The type of partner is a function of adoption stage 


\subsubsection{Entry rate of new mobile devices and partnerships}

Oshri and Weeber (2006) noted that partnerships in the mobile telecommunications industry require partners to both compete and collaborate. These researchers observed the case of Symbian where direct competitors collaborated to set an industry standard. It is expected that partnerships with competitors and industry consortia will have a positive effect in the entry rate of new converged mobile devices. Therefore,

Hypothesis 4c: The number of partnerships with competitors and industry consortia are positively related to the adoption of new mobile devices

\subsection{List of hypotheses}

The following hypotheses were developed to answer four questions about the adoption of Linux as the EOS for converged mobile devices.

Research question 1: What are the reasons to adopt Linux?

Hypothesis 1: The reasons for the adoption of Linux are a function of the adoption stage

Research question 2: What is the relationship between entry the rate of new converged mobile devices with Linux as the EOS and the entry rate of new adopters over time?

Hypothesis 2a: At early stages, the entry rate of new devices is positively related to the entry rate of new adopters 
Hypothesis 2b: At latter stages, the entry rate of new devices is negatively related to the entry rate of new adopters

Research question 3: How do the characteristics of the devices that adopted Linux as the EOS and product diversity change across adoption stages?

Hypothesis 3a: The type of device is a function of adoption stage

Hypothesis 3b: At early stages, product diversity is high

Hypothesis 3c: At latter stages, product diversity is low

Hypothesis 3d: The type of functions featured by devices with Linux as the EOS is a function of adoption stage

Research question 4: How do partnerships affect the adoption of Linux?

Hypothesis 4a: The reasons for partnership formation are a function of adoption stage

Hypothesis 4b: The type of partner is a function of adoption stage 
Hypothesis 4c: The number of partnerships with competitors and industry consortia are positively related to the adoption of new mobile devices 


\section{RESEARCH METHOD}

This chapter describes the research method used in this research. Sections 4.1 and 4.2 define the unit of analysis and the study period. Section 4.3 introduces the two samples used in this study. Section 4.4 details the data collection process. Section 4.5 explains the classifications used in this research. Section 4.6 presents the criteria used for the definition of adoption stages. Section 4.7 defines the measuring variables used. Finally, Section 4.8 provides details about the data analysis process.

\subsection{Unit of analysis}

The unit of analysis is a mobile device that uses Linux as the EOS and connects to cellular networks.

\subsection{Study period}

The study period starts in November 2000 with the launch announcement of the first mobile device having Linux as the EOS. It ends on December 2006, the last month for which data for this research was gathered.

\subsection{Samples of interest}

To test the hypotheses two samples are required: the mobile device sample and the partnership sample. 


\subsubsection{Mobile devices sample}

The mobile device sample is comprised of mobile devices with Linux as the EOS that were introduced during the study period. The mobile device sample is used to test all four hypotheses.

A three-step process was performed to identify the mobile devices launched with Linux as the EOS during the study period. For the first step, online searches were made using the Business Source Complete database. Business Source Complete is a comprehensive database for scholarly journals and business periodicals. To perform this search, the word Linux was entered in the search tool with the following words: "mobile device", "cellular phone", "cellphone", "PDA", and "smartphone".

In the second step, the Google search engine was used to undertake the online searches performed in the first step. These two steps allowed the identification of 57 mobile devices.

In the third step, for each mobile device, the name of the model was entered in the Google search engine followed by the command "site:" and the addresses of the manufacturers' and mobile distributors' websites.

A list of mobile devices was compiled using the information provided by these searches. For each mobile device, the following information was entered into a database: device model name, date of public launch announcement, and product specifications. 


\subsubsection{Partnerships sample}

The partnership sample was comprised of partnerships established by manufacturers that launched a mobile device with embedded Linux during the study period. This sample was used to test hypothesis $4 \mathrm{a}, 4 \mathrm{~b}$ and $4 \mathrm{c}$.

A three-step process was performed to identify the partnerships established by mobile manufacturers during the study period. For the first step, online searches were made using the Business Source Complete database. To perform this search, the word Linux was entered in the search tool with the following words: "alliance", "agreement", "collaboration", "cooperation" and "partnership". The number of hits for each combination was narrowed down to those containing the words "mobile device", "cellular phone", "cellphone", "PDA", and "smartphone".

In the second step the Google search engine was used to undertake the online searches performed in the first step.

In the third step, the word Linux was entered in the Google search engine combined with the words "alliance", "agreement", "collaboration", "cooperation" and "partnership", followed by the command "site:" and the addresses of mobile device manufacturers' websites. 
A database was created to include the names of the organizations that participated in each partnership and date in which the partnership was announced. In the cases where the partnership with a mobile device manufacturer involved more than one partner, $k$ individual partnership entries were generated to the database, where $k$ is equal to the number of partners.

\subsection{Data collection}

\subsubsection{New mobile device launch}

A new mobile device launch refers to the public announcement of the introduction of a previously unknown device with Linux as the EOS. A device is considered as being launched when the manufacturing company makes the model name public through announcements or press releases on its website. In the absence of a document from the manufacturing company, the following information sources were used to identify the mobile devices launched: news bulletins, company representative interviews, and tradeshow product presentations reports published in business periodicals and industry journals.

The articles found were examined to separate announcements about device launches from company announcements about prototype presentations and intentions to produce a new mobile device. A new device was considered as being launched on a given date if the article found in the online search included at least one of the words: "launch"; "unveil"; “present"; "introduce"; "ship"; “debut”; and "become available". 
Some manufacturing companies produce several launch announcements for the same model. For example, a certain mobile device is first launched in Japan and in Europe afterwards. In the case of multiple launch announcements for the same device, the device launch date was set to the date of the first announcement.

\subsubsection{New adopter}

A company that made a public launch announcement for the first time during the study period is considered a new adopter. The data for new adopters was collected from the launch announcement documents.

\subsubsection{Product specifications}

Product specifications for a mobile device included information on the manufacturing company's Internet page and its distributors' websites. For every individual model, the following product specification information was collected: the type of EOS (including the Linux kernel version), the GUI used, and a list of the mobile device's functions featured.

\subsubsection{Functions featured}

Functions featured refer to the group of software applications and services supported by a mobile device. Software applications might not require interaction with a higher level 
network to provide the intended output. This includes for instance, all programs that can run locally in the handset and use data previously stored on the mobile device.

Services supported comprise all functions featured by a mobile device that require an interaction with the cellular network or a cellular compatible network.

\subsection{Classifications}

\subsubsection{Function type}

In order to test hypothesis 3 , functions featured by mobile devices need to be classified by type. Documentation for converged mobile devices classifies featured functions according to the name of a commonly known mobile device. For instance, functions were found classified as cellular telephone functions, PDA functions or mobile computing functions. However, this classification did not offer clear boundaries for the identification of function types. Therefore, for the purpose of this research a method was developed to classify functions.

First, a list of all featured functions was gathered from the product specifications of the mobile device sample. These functions were then organized based on users' requirement satisfied into four types: (i) traditional cellular communication; (ii) advanced voice and data communications; (iii) information management; and (iv) entertainment functions. 


\section{Traditional cellular communications}

Traditional cellular communications functions are comprised of functions that satisfy wireless telephony communication connections and text functions supported on a cellular network. Included in this category are the functions that support the interaction of the user with the network and those that most commonly require services provided by the cellular network (e.g., call alert ring tones, short-messaging services and type cellular network supported).

\section{Advanced voice and data communication}

Advanced voice and data communication functions include those that satisfy the users' demands for voice transmission by means other than cellular networks. In addition, this category includes software applications that provide user format to data transferred over the cellular network or some other type of network. Some examples of these functions include: voice over wireless local area networks (WLANs), radio frequency identification (RFID), personal computing synchronization, videoconferencing, and email clients.

\section{Information management}

Information management include functions that satisfy users' demands for personal information management and advance computing services. Activity calendar, agenda, task lists, and commercial software file format viewers are some examples of information management functions. 


\section{Entertainment functions}

Entertainment functions include functions that satisfy users' demands for personal amusement. Examples of the functions include photographic and video cameras, players for different formats of audio and video, image and multimedia editor software programs, and games.

\subsubsection{Product type}

To test hypothesis 3 a classification of products by type is required. Products were classified according to the highest recurrence of featured functions of a type. As a result, a mobile device featuring a higher number of traditional cellular communications functions was classified as traditional cellular communication device. Converged mobile devices were classified in four product types: (i) traditional cellular communication device; (ii) advanced voice and data communications device; (iii) information management device; and (iv) entertainment device.

In the case where two or more types had the same count, the description of the target user as specified in the mobile device launch announcements was used to determine the product type.

For those cases were the information about functions supported was scarce, the target user description on the launch announcement determined the product type. 


\subsubsection{Partner type}

Participants in a partnership with a mobile device manufacturer were classified into four partner types: (i) competitors; (ii) suppliers; (iii) service providers; and (iv) industry consortia

In the case where more than one mobile device manufacturer participated in a partnership, a device manufacturer was randomly selected as the mobile device manufacturer that established the partnership. The competitor type included manufacturers of mobile devices.

The suppliers' type included embedded Linux providers, software development companies and semiconductor manufacturers.

The service providers' partner type included telecommunication mobile providers and Internet service companies.

The industry consortia type included forums, groups, associations and non-profit organizations.

\subsubsection{Reasons for adoption}

The reasons for adoption were classified into five categories, based on the five dimensions of innovation adoption identified by Rogers (1983). For each category, a set 
of keywords was generated by examining product launch announcements. Table 3 summarizes the five categories and the set of keywords used for each of them. 
Table 3: Keywords used to identify reasons for adoption

\begin{tabular}{|c|c|}
\hline Reason for adoption & Related keywords \\
\hline Relative advantage & $\begin{array}{ll}\text { - } & \text { Revenues } \\
\text { - } & \text { Time-to-market } \\
\text { - } & \text { Cost-reduction } \\
\text { - } & \text { Growth }\end{array}$ \\
\hline Compatibility & $\begin{array}{l}\text { - } \text { Compatible } \\
\text { - Standard } \\
\text { - Support } \\
\text { - Accessories }\end{array}$ \\
\hline Complexity & $\begin{array}{ll}\text { - } & \text { Easy } \\
\text { - Simple } \\
\text { - User-friendly } \\
\text { - Intuitive }\end{array}$ \\
\hline Triability & $\begin{array}{ll}\text { - } & \text { Flexible } \\
\text { - } & \text { Customize } \\
\text { - } & \text { Configurable } \\
\text { - } & \text { Testable } \\
\text { - } & \text { Modifiable }\end{array}$ \\
\hline Observability & $\begin{array}{ll}\text { - } & \text { Solid } \\
\text { - } & \text { Secure } \\
\text { - } & \text { High-quality } \\
\text { - Successful } \\
\text { - Reliable }\end{array}$ \\
\hline
\end{tabular}




\subsubsection{Reasons for partnership formation}

Following Dodourova (2003) based on the reasons to partner as stated in the announcement, a partnership can be: (i) product related; (ii) technology related; and (iii) industry/market related.

\subsection{Criteria to identify adoption stage transition}

Identification of adoption stages is required to test hypotheses 2,3 and 4 . A method similar to the one developed by Peng (2004), and then used by Napoles (2005) and Ali (2005), was used to identify the transition between adoption stages.

The main determinants for a change in stage were the adoption of newer revisions of Linux kernel and the adoption of new versions of the GUI.

The start of a new stage occurs when the following requirements are met:

i) a model launched has adopted a higher major revision of the Linux kernel or a newer release version of a GUI

ii) the last stage change occurred more than 12 months ago

iii) the minimal population of a stage must be equal to 10 percent of the study sample 


\subsection{Measurement variables}

\subsubsection{Adoption stages}

Adoption stages were assigned a consecutive number starting at stage 1 and leading up to the total number of stages identified as per the criteria listed in 4.6

\subsubsection{Entry of new mobile devices}

The rate of entry of new mobile devices is equal to the number of new equipment models launched at the end of each month.

\subsubsection{Density of new mobile devices}

Density of new mobile devices is equal to the cumulative number of new mobile devices launched at the end of each month

\subsubsection{Codification of function type}

To test hypothesis 3 , each function type was assigned a code as follows: Traditional cellular communication functions - code " $1 " ;$ advanced voice and data communications functions - code "2"; information management functions - code " 3 "; and entertainment functions - code "4". 


\subsubsection{Codification of product type}

To test hypothesis 3 , new mobile devices were assigned a product type code as follows: Traditional cellular communication devices - code "1"; advanced voice and data communications devices - code " 2 "; information management devices - code " 3 "; and entertainment devices - code " 4 ".

\subsubsection{Product diversity}

Product diversity was made equal to $1-\Sigma\left(p_{i}\right)^{2}$ where $p_{i}$ is the percentage of product type $i$ among the total number of products introduced. This is consistent with Peng (2004) and Ali (2005).

The minimum value of product diversity is 0 . It indicates that all products are of the same type.

The maximum value of product diversity is 0.9999 . It indicates that the products are drawn from types that are different.

\subsubsection{Codification of reasons for adoption}

Five categories for reasons for adoption were used in this research: relative advantage; compatibility; complexity; triability; and observability. A device might be adopted for more than one reason. Thus, a binary coding mechanism was used for each independent variable where a "1" value signifies that the mobile device was identified as adopted for 
that reason, and a "0" value means that it was not a reason for adoption. For example, if a device is identified as adopted for compatibility and triability reasons, compatibility and triability variables were assigned a value equal to "1", whereas relative advantage, complexity and observability were assigned a value equal to " 0 ".

\subsubsection{Number partnerships}

The number of partnerships is equal to the sum of partnerships announced at the end of each month.

\subsubsection{Cumulative number of partnerships}

Cumulative number of partnerships is the sum of all partnerships announced from the beginning of the study period at the end of each month.

\subsubsection{Codification of type of partner}

Companies classified as competitors were assigned a code equal to 1 . Companies classified as suppliers were assigned a code 2 . Companies classified as service providers were assigned a code 3 . The industry consortia created during the study period were assigned a code 4 . 


\subsubsection{Codification of reasons for partnership formation}

Reasons for partnership formation were classified into three types: product related; technology related; and industry/market related. A partnership may be established for more than one reason. Thus, a binary coding was used for each independent variable where a " 1 " value is used to represent that the partnership was formed for that particular reason, whereas a " 0 " value means that it was not a reason for partnership formation. For example, if a partnership was identified as formed for technology related and industry/market related reasons the variables for these two reasons were assigned a value equal to " 1 ", whereas the product related variable was assigned a value equal to " 0 ".

\subsection{Data analysis}

\subsubsection{Descriptive statistics}

Descriptive statistics for each of the variables were calculated. The descriptive statistics included minimum and maximum values, means, standard deviation, skewness and kurtosis. The latter two calculations were used to determine the normality of the data distributions. In addition, descriptive statistics were also computed for the variables at each adoption stage. SPSS 15.0 was used to perform the required calculations.

\subsubsection{Testing hypotheses}

The present research will follow testing methods and result evaluation criteria similar to those applied in previous TTM theses by Napoles (2005) and Ali (2005). However, the 
final selection of the test to be applied is based on the type of variables defined for the particular case of this research.

\subsubsection{Testing hypothesis 1}

Hypothesis 1 predicts that the reasons for adoption are a function of the adoption stage. To test hypothesis 1 , a contingency table with the frequencies of reasons for adoption at each adoption stage will be created. The Chi-square test will be used. If the Chi-square test shows that the result of the association between rows and columns was significant at $\mathrm{p}<.05$, this writer will conclude that the reasons for adoption are a function of adoption stage. Otherwise, it will be concluded that hypothesis 1 is not supported.

\subsubsection{Testing hypothesis $2 a$ and $2 b$}

Hypothesis 2 a predicts that at early stages, the entry rate of new devices is positively related to the entry rate of new adopters, and hypothesis $2 b$ predicts that at late stages, the entry rate of new devices is negatively related to the entry rate of new adopters. First it will be determined if the entry rate of new devices and the entry rate of new adopters are normally distributed at different adoption stages. If the data is normally distributed, a Pearson correlation test will be used. If the data is not normally distributed, a Spearman correlation will be used. If for the Pearson correlation test, the correlation coefficient was positive at $\mathrm{p}<.01$, or if the Spearman correlation test was significant at $\mathrm{p}<.05$, the writer will conclude that the entry rate of new devices is related to the entry rate of new adopters. 


\subsubsection{Testing hypothesis $3 \mathrm{a}$}

Hypothesis 3a predicts that the type of mobile devices launched is a function of adoption stage. Normality of the distribution of the types of mobile devices launched for each adoption stage will be checked. On one hand, if the data is normally distributed, multiple comparisons of product diversity will be made between every two adjacent stages using a one-way ANOVA test. If the mean difference is significant between two stages at $\mathrm{p}<.05$, this writer will conclude that product diversity is significantly different between the two stages. On the other hand, if the data is not normally distributed, the Mann-Whitney U test will be used to compare the mean ranks of product diversity between different stages. If the mean rank is significantly between two stages at $p<.10$, this writer will conclude that the types of mobile devices launched is significantly different between the two stages.

\subsubsection{Testing hypothesis $3 b$}

Hypothesis $3 \mathrm{~b}$ predicts that at early stages, high variations in product diversity occur among converged mobile devices launched and hypothesis $3 \mathrm{c}$ predicts that at latter stages, low variations in product diversity occur among converged mobile devices launched. Product diversity will be calculated for each month of the study period. Normality of the distributions for each adoption stage will be checked. On one hand, if the data is normally distributed, multiple comparisons of product diversity will be made between every two adjacent stages using a one-way ANOVA test. If the mean difference 
is significant between two stages at $\mathrm{p}<.05$, this writer will conclude that product diversity is significantly different between the two stages. On the other hand, if the data is not normally distributed, the Mann-Whitney $U$ test will be used to compare the mean ranks of product diversity between different stages. If the mean rank is significantly between two stages at $\mathrm{p}<.10$, this writer will conclude that the variation on product diversity is significantly different between the two stages.

\subsubsection{Testing hypothesis $3 \mathrm{~d}$}

Hypothesis $3 \mathrm{~d}$ predicts that the type of functions featured by converged mobile devices is a function of adoption stage. The type of functions featured by mobile devices launched will be calculated for each month of the study period. Normality of the distributions for each adoption stage will be checked. On one hand, if the data is normally distributed, multiple comparisons of product diversity will be made between every two adjacent stages using a one-way ANOVA test. If the mean difference is significant between two stages at $\mathrm{p}<.05$, this writer will conclude that product diversity is significantly different between the two stages. On the other hand, if the data is not normally distributed, the Mann-Whitney $U$ test will be used to compare the mean ranks of product diversity between different stages. If the mean rank is significantly between two stages at $p<.10$, this writer will conclude that the number of services and applications supported per type is significantly different between the two stages. 


\subsubsection{Testing hypothesis $4 a$}

Hypothesis 4a predicts that the reasons for partnership formation are a function of adoption stage. The cumulative reasons for partnership formation will be calculated for each month of the study period. Normality of the distributions for each adoption stage will be checked. On one hand, if the data is normally distributed, multiple comparisons of product diversity will be made between every two adjacent stages using a one-way ANOVA test. If the mean difference is significant between two stages at $p<.05$, this writer will conclude that product diversity is significantly different between the two stages. On the other hand, if the data is not normally distributed, the Mann-Whitney U test will be used to compare the mean ranks of product diversity between different stages. If the mean rank is significantly between two stages at $p<.10$, this writer will conclude that the reasons for partnership formation is significantly different between the two stages.

\subsubsection{Testing hypothesis $4 \mathrm{~b}$}

Hypothesis $4 \mathrm{~b}$ predicts that the type of partner is a function of adoption stage. To test hypothesis $4 \mathrm{~b}$, a contingency table with the frequencies of type of partner at each adoption will be created. The Chi-square test will be used. If the Chi-square test shows that the result of the association between rows and columns was significant at $p<.05$, this writer will conclude that the type of partner is a function of adoption stage. 


\subsubsection{Testing hypothesis $4 c$}

Hypothesis $4 \mathrm{c}$ predicts that the number of partnerships with competitors and industry consortia are positively related to the adoption of new mobile devices. Cumulative data for the number of partnerships formed three months prior to the adoption will be used to measure the impact of partnerships on new products launched. Previous studies have considered that quarterly information has a substantial influence on companies' decision making (Peng, 2004; Wade, 1996).

Cumulative data of the number of partnerships for the previous three months will be calculated for each month of the study period. Normality of the distributions for each adoption stage will be checked. On one hand, if the data is normally distributed, a Pearson correlation will be made. On the other hand, if the data is not normally distributed, a Spearman correlation will be used. If the coefficient in the Pearson correlation test is positive and significant at $\mathrm{p}<.01$, or if the coefficient in the Spearman correlation is positive and significant at $\mathrm{p}<.05$, this writer will conclude that number of partnerships with competitors and industry consortia is positively correlated to the number of new mobile devices. 


\section{RESULTS}

This chapter provides the results. Section 5.1 describes the two samples used. Section 5.2 provides descriptive statistics. Section 5.3 describes the partnerships of converged mobile device manufacturers. Section 5.4 provides information about the adoption stages. Sections 5.5 to 5.8 provide the results of testing the hypotheses. Section 5.9 provides a summary of the test results.

\subsection{Samples}

\subsubsection{Mobile devices sample}

The mobile device sample was comprised of 57 models launched during the study period.

Table 4 provides a breakdown of the 57 mobile devices by product type. Table 5 provides descriptive statistics for the number of functions supported by product type. The 57 mobile devices supported 107 functions. Table 5 provides the descriptive statistics for these 107 functions by product type. 
Table 4: Number of mobile devices by type of product

$(\mathrm{N}=57$ mobile devices)

\begin{tabular}{|l|c|c|c|c|}
\hline & $\begin{array}{c}\text { Traditional } \\
\text { cellular } \\
\text { communication }\end{array}$ & $\begin{array}{c}\text { Additional } \\
\text { voice/data } \\
\text { communication }\end{array}$ & $\begin{array}{l}\text { Information } \\
\text { management }\end{array}$ & Entertainment \\
\hline $\begin{array}{l}\text { Number of } \\
\text { new mobile } \\
\text { devices } \\
\text { launched }\end{array}$ & 13 & 4 & 26 & 14 \\
\hline $\begin{array}{l}\text { Percentage of } \\
\text { the sample }\end{array}$ & $22.8 \%$ & $7.0 \%$ & $45.6 \%$ & $24.6 \%$ \\
\hline
\end{tabular}

Table 5: Descriptive statistics for the number of functions supported by type of product

$(\mathrm{N}=107$ functions supported by 57 new mobile devices)

\begin{tabular}{|l|c|c|c|c|c|}
\hline & $\begin{array}{c}\text { Traditional } \\
\text { cellular } \\
\text { communication }\end{array}$ & $\begin{array}{c}\text { Additional } \\
\text { voice/data } \\
\text { communication }\end{array}$ & $\begin{array}{c}\text { Information } \\
\text { management }\end{array}$ & $\begin{array}{c}\text { Entertainment } \\
\text { per } \\
\text { device }\end{array}$ \\
\hline Mean & 7.44 & 4.74 & 7.46 & 6.35 & 25.98 \\
\hline $\begin{array}{l}\text { Standard } \\
\text { deviation }\end{array}$ & 4.532 & 2.357 & 5.117 & 4.809 & 13.565 \\
\hline Minimum & 1 & 1 & 0 & 0 & 3 \\
\hline Maximum & 16 & 11 & 18 & 18 & 55 \\
\hline
\end{tabular}


Appendix 2 provides the list of mobile devices launched during the study period arranged by launch date. The table includes the model name, manufacturing company and type of product.

\subsubsection{Partnerships sample}

The partnership sample was comprised of 40 partnership agreements which included 77 partners. Appendix 3 provides the list of partnerships in the sample arranged by date. Appendix 3 includes the names of participants and partner types. Table 6 provides a breakdown of partners by type and Figure 1 shows the partners' entry rate over the study period.

Table 6: Breakdown of partners by type

$$
(\mathrm{N}=77 \text { partners })
$$

\begin{tabular}{|l|c|c|c|c|}
\hline & Competitors & Supplier & $\begin{array}{c}\text { Service } \\
\text { provider }\end{array}$ & $\begin{array}{c}\text { Industry } \\
\text { consortia }\end{array}$ \\
\hline Count & 21 & 35 & 12 & 9 \\
\hline $\begin{array}{l}\text { Percentage of } \\
\text { the sample }\end{array}$ & 27.3 & 45.5 & 15.6 & 11.7 \\
\hline
\end{tabular}


Figure 1: Partners entry rate over the study period

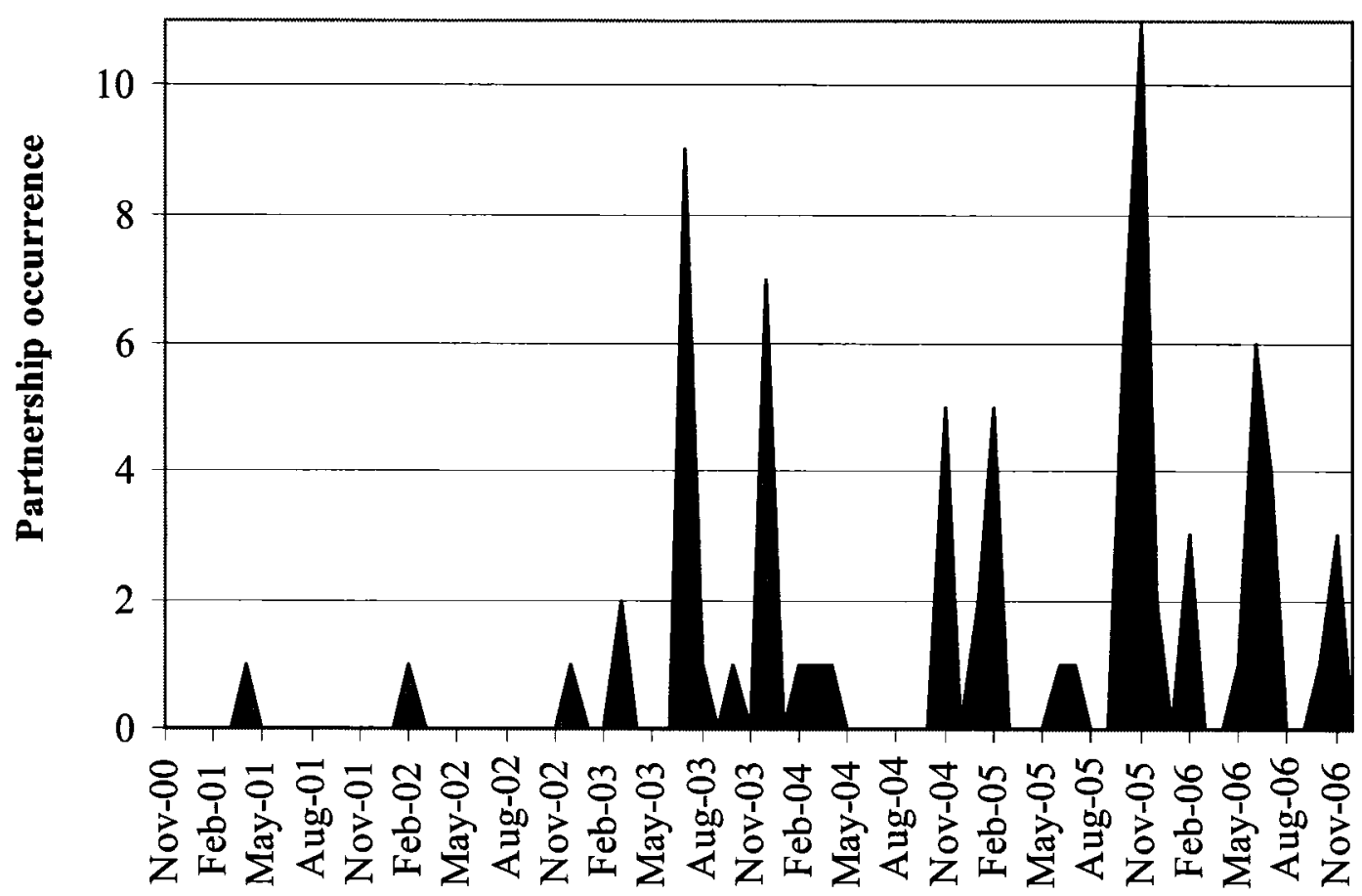

\section{$5.2 \quad$ Descriptive statistics}

\subsubsection{New mobile device and new adopters}

Table 7 provides descriptive statistics of the five variables that pertain to mobile devices and new adopters used to test hypotheses: entry rate of new mobile device, density of new mobile devices, product diversity, new adopters' entry rate and cumulative number of new adopters. The study period comprises 74 months. 
Table 7: Descriptive statistics for the five variables that pertain to mobile devices and new adopters

$$
(\mathrm{N}=74 \text { months })
$$

\begin{tabular}{|l|c|c|c|c|c|c|}
\hline Variables & Min & Max & Mean & $\begin{array}{l}\text { Standard } \\
\text { deviation }\end{array}$ & $\begin{array}{l}\text { Skewness } \\
\text { Std.Error=0.28 }\end{array}$ & $\begin{array}{l}\text { Kurtosis } \\
\text { Std.Error=0.55 }\end{array}$ \\
\hline $\begin{array}{l}\text { Entry rate } \\
\text { of new } \\
\text { mobile } \\
\text { devices }\end{array}$ & 0 & 9 & 0.77 & 1.46 & 3.4 & 14.6 \\
\hline $\begin{array}{l}\text { Density of } \\
\text { new } \\
\text { mobile } \\
\text { devices }\end{array}$ & 1 & 57 & 14.66 & 17.40 & 1.3 & 0.29 \\
\hline $\begin{array}{l}\text { Product } \\
\text { diversity }\end{array}$ & 0 & 0.7 & 0.45 & 0.21 & -1.0 & 0.28 \\
\hline $\begin{array}{l}\text { New } \\
\text { adopters } \\
\text { entry rate }\end{array}$ & 0 & 3 & 0.38 & 0.77 & 1.8 & 2.45 \\
\hline $\begin{array}{l}\text { Cumulative } \\
\text { number of } \\
\text { new } \\
\text { adopters }\end{array}$ & 1 & 28 & 8.78 & 8.52 & 1.0 & -0.43 \\
\hline
\end{tabular}

The value of skewness provides a measure of symmetry for the distribution values around the sample's mean. Kurtosis is a measure of peakness of the sample data relative to normal distribution. The results displayed in Table 7 show that none of the variables is normally distributed. For each of the five variables shown in Table 7 skewness is greater than twice the standard error.

The positive skewness values for the entry rate of new mobile devices, density of new mobile devices, new adopters' entry rate and cumulative number of new adopters indicate that the corresponding distributions are skewed to the right. The negative result for 
product diversity indicates that the corresponding distribution is skewed to the left. Furthermore, kurtosis values for density of new mobile devices and product diversity suggest that these distributions show lower peakness than normal. Kurtosis results for the entry rate of new mobile devices and new adopters' entry rate suggest that the resulting distributions are more peaked than normal.

Figures 2 and 3 show the entry rate of new mobile devices and density of new mobile devices over time.

Figure 2: Entry rate of new mobile devices over time

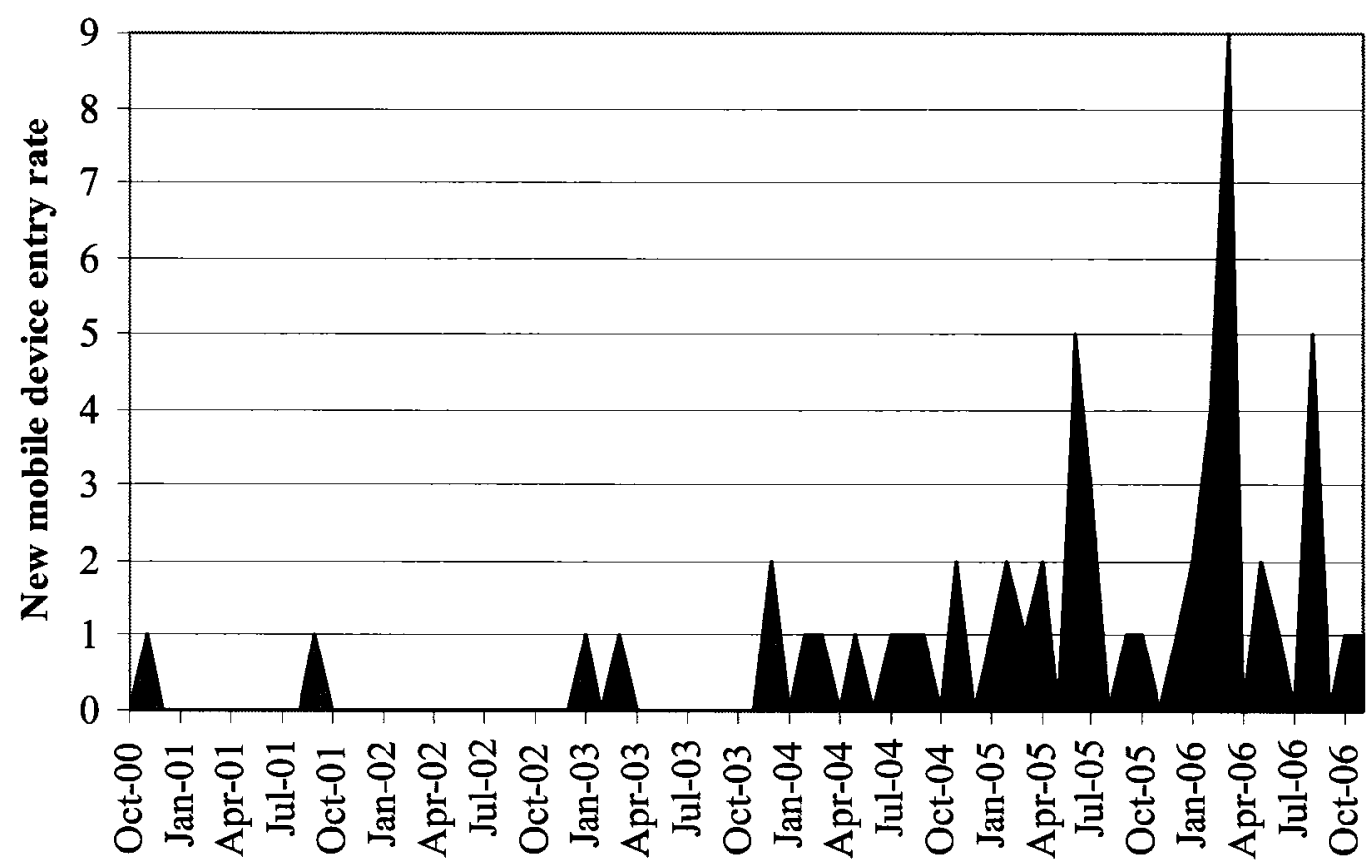


Figure 3: Density of new mobile devices over time

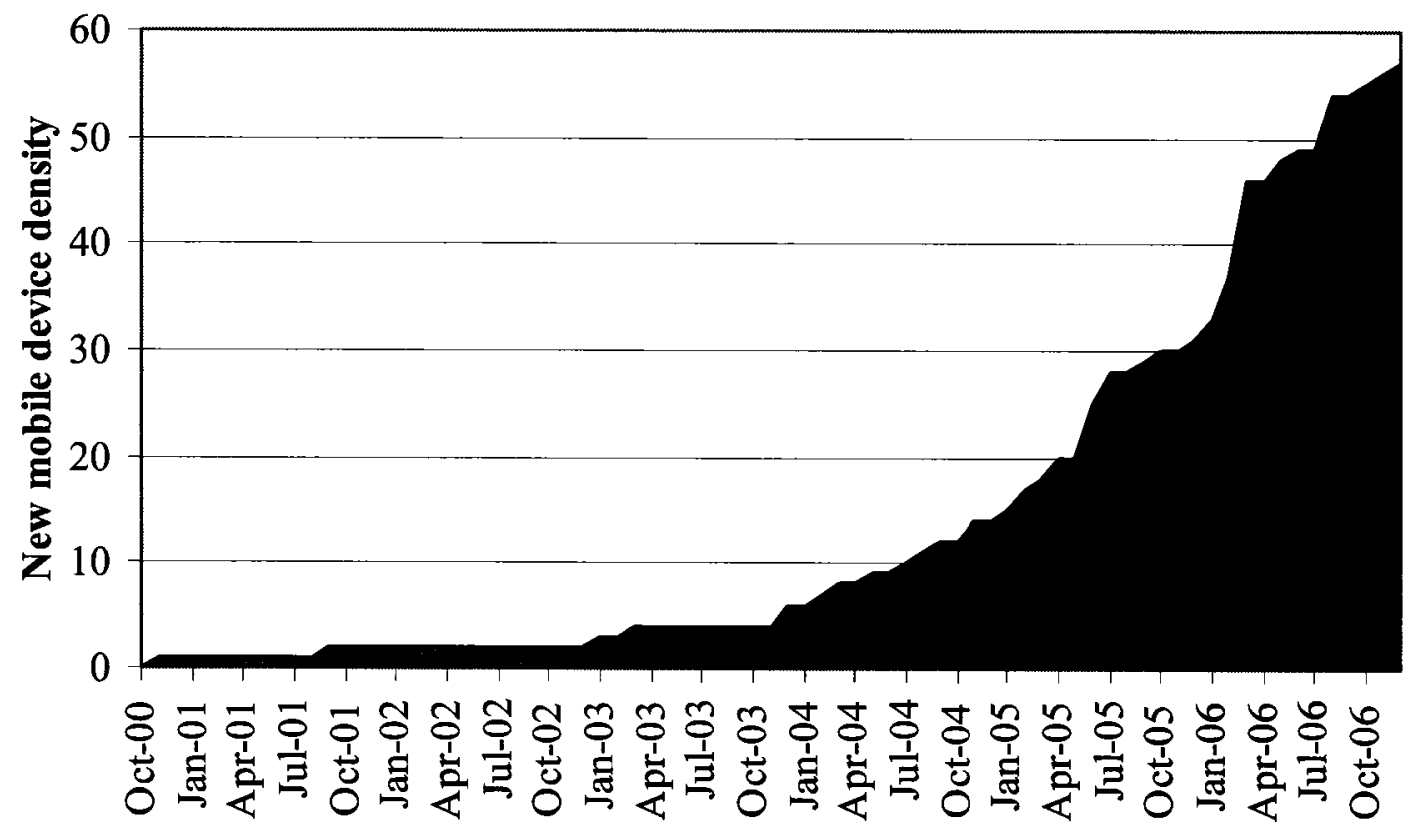

Figure 4 illustrates product diversity over time.

Figure 4: Product diversity over time

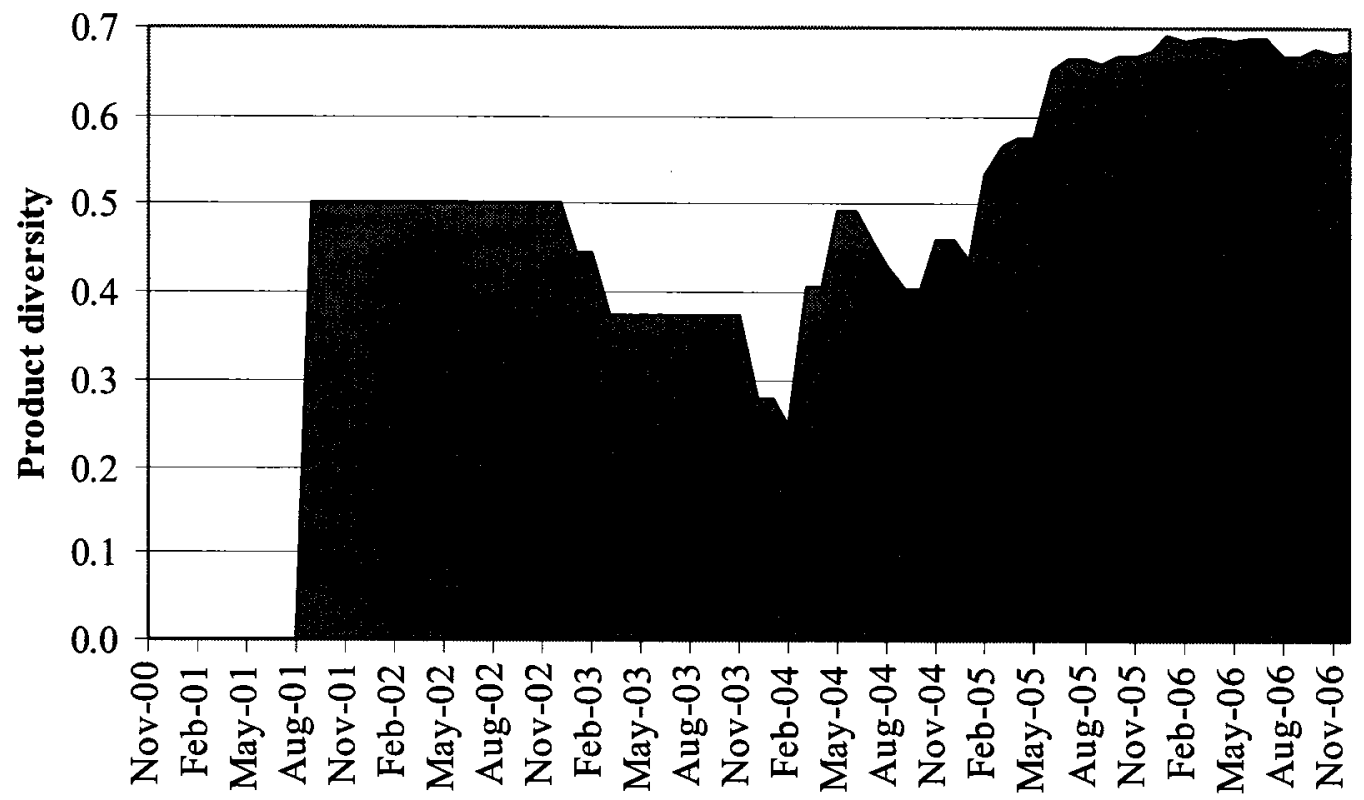


Table 8 provides a count of the reasons for adoption by type.

Table 8: Reasons for adoption

\begin{tabular}{|l|c|c|}
\hline Reason for adoption & Occurrence & Percentage \\
\hline Relative advantage & 29 & 19.9 \\
\hline Compatibility & 47 & 32.2 \\
\hline Complexity & 19 & 13.0 \\
\hline Triability & 39 & 26.7 \\
\hline Observability & 12 & 8.2 \\
\hline Total & 146 & 100.0 \\
\hline
\end{tabular}

\subsubsection{Product specifications}

Table 9 provides the descriptive statistics for the functions, applications and services supported by mobile devices in the sample. 
Table 9: Descriptive statistics for product specifications

$$
(\mathrm{N}=107 \text { functions })
$$

\begin{tabular}{|l|c|c|c|c|c|l|}
\hline Variables & Min & Max & Mean & $\begin{array}{l}\text { Standard } \\
\text { deviation }\end{array}$ & $\begin{array}{l}\text { Skewness } \\
\text { Std.Error=0.316 }\end{array}$ & $\begin{array}{l}\text { Kurtosis } \\
\text { Std.Error=0.623 }\end{array}$ \\
\hline $\begin{array}{l}\text { Number of } \\
\text { functions } \\
\text { supported }\end{array}$ & 3 & 55 & 26.0 & 13.56 & 0.165 & -0.967 \\
\hline $\begin{array}{l}\text { Number of } \\
\text { applications } \\
\text { supported }\end{array}$ & 2 & 14 & 7.7 & 3.41 & -0.276 & -1 \\
\hline $\begin{array}{l}\text { Number of } \\
\text { services } \\
\text { supported }\end{array}$ & 1 & 43 & 18.3 & 11.53 & 0.263 & -1.034 \\
\hline
\end{tabular}

Skewness measures for all the three variables shown in Table 9 are less than twice the standard error. In addition, kurtosis is within the -2 to +2 range. This suggests that the distributions for number of functions, applications and services supported are normally distributed.

\subsection{Partnerships}

Table 10 provides the descriptive statistics for the 77 partners in the sample and Table 11 provides the breakdown of the 114 reasons for partnership formation by type. 
Table 10: Descriptive statistics for partners and cumulative number of partners

$$
(\mathrm{N}=74 \text { months })
$$

\begin{tabular}{|l|c|c|c|c|c|l|}
\hline Variables & Min & Max & Mean & Standard & Skewness & Kurtosis \\
\hline Partners & 0 & 11 & 1.04 & 2.192 & 2.753 & Std.Error=0.552 \\
\hline Cumulative & 0 & 77 & 24.38 & 24.929 & 0.767 & -0.684 \\
number of \\
partners
\end{tabular}

Table 11: Reasons for partnership formation

\begin{tabular}{|l|c|c|}
\hline Motive & Occurrence & Percent \\
\hline Product related & 32 & 28.1 \\
\hline Market / industry related & 34 & 29.8 \\
\hline Technology related & 48 & 42.1 \\
\hline Total & 114 & 100.0 \\
\hline
\end{tabular}

\subsection{Adoption stages}

\subsubsection{Identification of adoption stages}

Table 12 illustrates how the stage transitions were determined. The departure point of adoption stage 1 is marked in November 2000 by the launch announcement of Palmi by PalmPalm, the first ever mobile device featuring Linux EOS. Palmi was reported to have 
an embedded Linux based on the 2.4 .0 kernel and Qt/Embedded as GUI. Table 12 summarizes the potential changes and the effective changes in adoption stages according to the criteria defined on 4.6 .

Table 12: Stage transitions based on changes in Linux kernel major revisions and GUI

\begin{tabular}{|l|l|c|l|l|}
\hline $\begin{array}{l}\text { Type of } \\
\text { argument }\end{array}$ & Value & Year/month & $\begin{array}{l}\text { Model name } \\
\text { (Manufacturer) }\end{array}$ & $\begin{array}{l}\text { Stage } \\
\text { transition }\end{array}$ \\
\hline $\begin{array}{l}\text { GUI, Linux } \\
\text { kernel }\end{array}$ & $\begin{array}{l}\text { Qt/Embedded, } \\
\text { Linux 2.4.0 }\end{array}$ & $2000 / 11$ & $\begin{array}{l}\text { Palmi } \\
\text { (PalmPalm) }\end{array}$ & Start of stage 1 \\
\hline GUI & Qtopia & $2004 / 11$ & $\begin{array}{l}\text { Datang 3G } \\
\text { Linux (Datang } \\
\text { Mobile) }\end{array}$ & Start of stage 2 \\
\hline GUI & Chameleon UI & $2005 / 07$ & $\begin{array}{l}\text { A910 } \\
\text { (Motorola) }\end{array}$ & No change \\
\hline GUI & Qtopia 2.2 & $2006 / 01$ & $\begin{array}{l}\text { GW1 (WNC } \\
\text { Wistron NeWeb } \\
\text { Corporation) }\end{array}$ & Start of stage 3 \\
\hline Linux Kernel & $\begin{array}{l}\text { Linux kernel } \\
2.6 . x\end{array}$ & $2006 / 02$ & $\begin{array}{l}\text { Dreamphone } \\
\text { G500i } \\
\text { (Grundig) }\end{array}$ & No change \\
\hline GUI & GTK+2.x & $2006 / 11$ & Neo1973 (FIC) & No change \\
\hline
\end{tabular}

The second adoption stage began in November 2004 when Datang Mobile launched Datang 3G Linux with Qtopia as GUI. This announcement took place more than 12 months after the last stage transition and the population minimum requirement was met. 
In July 2005, Motorola launched the A910 with Chameleon UI. However, when this announcement was made no more than 12 months had already passed since the last stage transition. As a result no change in stage was recorded.

Adoption stage 3 began when WNC Wistron NeWeb Corporation launched the GW1 with Qtopia 2.2 as GUI. The announcement was made in January 2006 and more than 12 months had passed since the last stage transition.

In February 2006, Grundig published the launch announcement of Dream phone G500i with embedded Linux based on a 2.6.x kernel. Provided that no more than 12 months had passed since the last stage transition, no change was produced.

Finally, FIC launched NEO 1973 with GTK+2.x as GUI in November 2006. No change in adoption stage was produced given that no more that 12 months had passed since the last stage transition.

\subsubsection{New mobile devices by stage of adoption}

Table 13 provides the breakdown of new mobile devices launched by stage of adoption. The data shown here was used to test hypotheses 2 and 4 . 
Table 13: Number of new mobile devices by adoption stage

\begin{tabular}{|l|l|c|c|c|c|}
\hline $\begin{array}{l}\text { Adoption } \\
\text { stages }\end{array}$ & $\begin{array}{l}\text { Beginning } \\
\text { date } \\
\text { (year/month) }\end{array}$ & $\begin{array}{l}\text { Duration } \\
\text { in months }\end{array}$ & $\begin{array}{l}\text { Number } \\
\text { of new } \\
\text { devices }\end{array}$ & $\begin{array}{l}\text { Percentage of } \\
\text { mobile device } \\
\text { sample }\end{array}$ & $\begin{array}{l}\text { Cumulative } \\
\text { percentage }\end{array}$ \\
\hline Stage 1 & $2000 / 11$ & 48 & 12 & 21.1 & 21.1 \\
\hline Stage 2 & $2004 / 11$ & 14 & 19 & 33.3 & 54.4 \\
\hline Stage 3 & $2006 / 01$ & 12 & 26 & 45.6 & 100 \\
\hline Total & & & 57 & 100 & \\
\hline
\end{tabular}

\subsubsection{Product diversity by stage of adoption}

Table 14 provides statistics for product diversity per stage of adoption and Figure 5 illustrates the changes across the three stages identified.

Table 14: Product diversity by adoption stage

\begin{tabular}{|l|c|c|c|}
\hline $\begin{array}{l}\text { Adoption } \\
\text { stage }\end{array}$ & Duration in months & $\begin{array}{l}\text { Percentage of } \\
\text { sample duration }\end{array}$ & $\begin{array}{l}\text { Product diversity } \\
\text { mean }\end{array}$ \\
\hline Stage 1 & 48 & 64.9 & 0.34 \\
\hline Stage 2 & 14 & 18.9 & 0.59 \\
\hline Stage 3 & 12 & 16.2 & 0.68 \\
\hline Total & 74 & 100 & 0.45 \\
\hline
\end{tabular}

Product diversity increased rapidly during stages 1 and 2. In contrast slow increments are observed in stage 3 . 
Figure 5: Product diversity by adoption stage

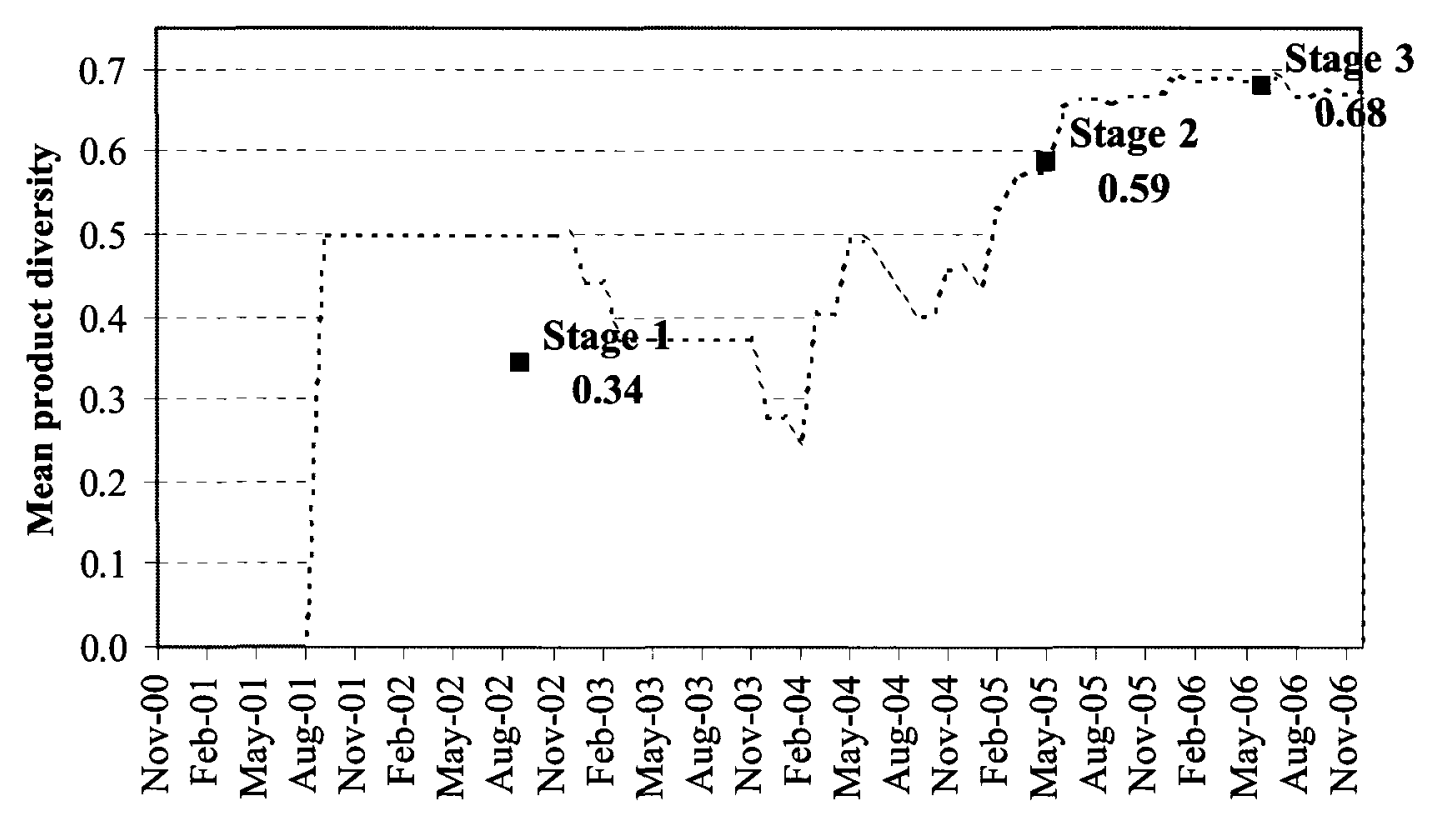

\subsubsection{Number of partnerships by stage of adoption}

Table 15 provides the number of partnerships and the percentage of the total sample by adoption stage. 
Table 15: Number of partnerships by adoption stage

\begin{tabular}{|l|c|c|c|c|}
\hline $\begin{array}{l}\text { Adoption } \\
\text { stage }\end{array}$ & $\begin{array}{l}\text { Beginning date } \\
\text { (year/month) }\end{array}$ & $\begin{array}{l}\text { Number of } \\
\text { partnerships }\end{array}$ & $\begin{array}{l}\text { Percentage of } \\
\text { partnership sample }\end{array}$ & $\begin{array}{l}\text { Cumulative } \\
\text { percentage }\end{array}$ \\
\hline Stage 1 & $2000 / 11$ & 26 & 33.8 & 33.8 \\
\hline Stage 2 & $2004 / 11$ & 33 & 42.9 & 76.6 \\
\hline Stage 3 & $2006 / 01$ & 18 & 23.4 & 100 \\
\hline Total & & 77 & 100 & \\
\hline
\end{tabular}

5.5 Hypothesis 1: The reasons for the adoption of Linux are a function of the adoption stage

The Chi-square test was used to test hypothesis 1 . Table 16 shows the contingency table for reasons for adoption per adoption stage.

Table 16: Contingency table for reasons for adoption per adoption stage

Contingency table (cells provide counts)

\begin{tabular}{|l|c|c|c|c|}
\hline $\begin{array}{l}\text { Reasons for } \\
\text { adoption }\end{array}$ & Stage 1 & Stage 2 & Stage 3 & Total \\
\hline $\begin{array}{l}\text { Relative } \\
\text { advantage }\end{array}$ & 6 & 9 & 14 & 29 \\
\hline Compatibility & 8 & 16 & 23 & 47 \\
\hline Complexity & 4 & 6 & 9 & 19 \\
\hline Triability & 6 & 14 & 19 & 39 \\
\hline Observability & 2 & 2 & 8 & 12 \\
\hline
\end{tabular}


Table 17 shows the test used to measure the association between reasons for adoption and adoption stage.

Table 17: Chi-square test for reasons for adoption per adoption stage

Adoption stage * Reasons for adoption cross tabulation

\begin{tabular}{|c|c|c|c|c|c|c|}
\hline \multirow{2}{*}{$\begin{array}{l}\text { Adoption } \\
\text { stage }\end{array}$} & \multicolumn{5}{|c|}{ Reasons for adoption } & \multirow[t]{2}{*}{ Total } \\
\hline & $\begin{array}{l}\text { Relative } \\
\text { advantage }\end{array}$ & Compatibility & Complexity & Triability & Observability & \\
\hline $\begin{array}{l}\text { Stage 1 } \\
\text { Count }\end{array}$ & 6 & 8 & 4 & 6 & 2 & 26 \\
\hline Expected & 5.2 & 8.4 & 3.4 & 6.9 & 2.1 & 26.0 \\
\hline $\begin{array}{l}\text { Stage } 2 \\
\text { Count }\end{array}$ & 9 & 16 & 6 & 14 & 2 & 47 \\
\hline Expected & 9.3 & 15.1 & 6.1 & 12.6 & 3.9 & 47.0 \\
\hline $\begin{array}{l}\text { Stage } 3 \\
\text { Count }\end{array}$ & 14 & 23 & 9 & 19 & 8 & 73 \\
\hline Expected & 14.5 & 23.5 & 9.5 & 19.5 & 6.0 & 73.0 \\
\hline $\begin{array}{l}\text { Total } \\
\text { Count }\end{array}$ & 29 & 47 & 19 & 39 & 12 & 146 \\
\hline Expected & 29.0 & 47.0 & 19.5 & 39.0 & 12.0 & 146.0 \\
\hline
\end{tabular}

\section{Chi-Square Tests}

\begin{tabular}{|l|l|l|l|}
\hline & Value & Df & $\begin{array}{l}\text { Asymp. Sig. } \\
\text { (2-sided) }\end{array}$ \\
\hline Pearson Chi-Square & $2.264 \mathrm{a}$ & 8 & .972 \\
\hline Likelihood Ratio & 2.382 & 8 & .967 \\
\hline $\begin{array}{l}\text { Linear-by-Linear } \\
\text { Association }\end{array}$ & .411 & 1 & .521 \\
\hline N of Valid Cases & 146 & & \\
\hline
\end{tabular}

a. 3 cells $(20.0 \%)$ have expected count less than 5 . The minimum expected count is 2.14

From the results, three cells have expected count of less than 5 . Therefore, in order to comply with the requirements of a Chi-square test only the three reasons for adoption 
with the highest incidence over the study period will be considered. A Chi-Square test was performed using the reasons for adoption relative advantage, compatibility and triability.

Table 18: Chi-square test for reasons for adoption per adoption stage

Adoption stage * Reasons for adoption cross tabulation

\begin{tabular}{|l|c|c|c|c|}
\hline \multirow{2}{*}{ Adoption stage } & \multicolumn{3}{|l|}{ Reasons for adoption } & \multirow{2}{*}{ Total } \\
\cline { 2 - 4 } & $\begin{array}{l}\text { Relative } \\
\text { advantage }\end{array}$ & Compatibility & Triability & \\
\hline $\begin{array}{l}\text { Stage 1 } \\
\text { Count }\end{array}$ & 6 & 8 & 6 & 20 \\
\hline Expected & 5.0 & 8.2 & 6.8 & 20.0 \\
\hline $\begin{array}{l}\text { Stage 2 } \\
\text { Count }\end{array}$ & 9 & 16 & 14 & 39 \\
\hline Expected & 9.8 & 15.9 & 13.2 & 39.0 \\
\hline $\begin{array}{l}\text { Stage 3 } \\
\text { Count }\end{array}$ & 14 & 23 & 19 & 56 \\
\hline Expected & 14.1 & 22.9 & 19.0 & 56.0 \\
\hline $\begin{array}{l}\text { Total } \\
\text { Count }\end{array}$ & 29 & 47 & 39 & 115 \\
\hline Expected & 29.0 & 47.0 & 39.0 & 115.0 \\
\hline
\end{tabular}

Chi-Square Tests

\begin{tabular}{|l|l|l|l|}
\hline & Value & Df & $\begin{array}{l}\text { Asymp. Sig. } \\
\text { (2-sided) }\end{array}$ \\
\hline Pearson Chi-Square & $.393(\mathrm{a})$ & 4 & .983 \\
\hline Likelihood Ratio & .388 & 4 & .983 \\
\hline $\begin{array}{l}\text { Linear-by-Linear } \\
\text { Association }\end{array}$ & .0 .76 & 1 & .783 \\
\hline N of Valid Cases & 115 & & \\
\hline
\end{tabular}

a. 0 cells $(0 \%)$ have expected count less than 5 . The minimum expected count is 5.04 
The results on Table 18 show that there is no significant association between the reasons for adoption and the stage of adoption. Therefore, hypothesis 1 is not supported.

\subsection{Hypothesis 2}

5.6.1 Hypothesis 2a: At early stages, the entry rate of new devices is positively related to the entry rate of new adopters

In order to test hypothesis 2 , the normality of the distribution of new adopters and the cumulative number of new adopters needs to be determined at each adoption stage. Table 19 shows the descriptive statistics for new adopters and the density of adopters per adoption stage. 
Table 19: Descriptive statistics for new adopters and density of adopters per adoption stage

New mobile devices (per month)

\begin{tabular}{|l|l|l|l|l|l|l|l|l|l|}
\hline $\begin{array}{l}\text { Adoption } \\
\text { stage }\end{array}$ & $\mathbf{N}$ & Min & Max & Mean & $\begin{array}{l}\text { Std. } \\
\text { dev. }\end{array}$ & & Skewness & Surtosis \\
\hline Stage 1 & 48 & 0 & 2 & .25 & .484 & 1.765 & .343 & 2.398 & .674 \\
\hline Stage 2 & 14 & 0 & 5 & 1.36 & 1.393 & 1.440 & .597 & 2.586 & 1.154 \\
\hline Stage 3 & 12 & 0 & 9 & 2.17 & 2.657 & 1.809 & .637 & 3.330 & 1.232 \\
\hline
\end{tabular}

Cumulative number of adopters (per month)

\begin{tabular}{|c|c|c|c|c|c|c|c|c|c|}
\hline \multirow{2}{*}{$\begin{array}{l}\text { Adoption } \\
\text { stage }\end{array}$} & \multirow[t]{2}{*}{$\mathbf{N}$} & \multirow[t]{2}{*}{ Min } & \multirow[t]{2}{*}{ Max } & \multirow[t]{2}{*}{ Mean } & \multirow{2}{*}{$\begin{array}{l}\text { Std. } \\
\text { dev. }\end{array}$} & \multicolumn{2}{|c|}{ Skewness } & \multicolumn{2}{|l|}{ Kurtosis } \\
\hline & & & & & & Statistic & \begin{tabular}{|l|}
$\begin{array}{l}\text { Std. } \\
\text { error }\end{array}$ \\
\end{tabular} & Statistic & $\begin{array}{l}\text { Std. } \\
\text { error }\end{array}$ \\
\hline Stage 1 & 48 & 1 & 7 & & 2.078 & & .343 & .907 & .674 \\
\hline Stage 2 & 14 & 9 & 18 & 14.36 & 3.692 & -.470 & .597 & -1.549 & 1.154 \\
\hline Stage 3 & 12 & 19 & 28 & 24.42 & 2.746 & -.461 & .637 & -.173 & 1.232 \\
\hline
\end{tabular}

Table 19 shows that the number of new devices is not normally distributed for all stages.

Therefore, the Spearman correlation was used for each stage to test the relation between the entry rate of new devices and the entry rate of new adopters.

For stage 1, the Spearman correlation coefficient for new mobile devices and new adopters is 0.710 with sig. of 0.000 . Given that the coefficient is positive and significant at $p<.01$, this suggests that at stage 1 there is a positive relationship between the number of new devices and the number of new adopters. Appendix 5 shows a table with detailed results for testing hypothesis $2 \mathrm{a}$. 
For stage 2, the Spearman correlation coefficient for new mobile devices and new adopters is 0.690 with sig. of 0.006 . Given that the coefficient is positive and significant at $\mathrm{p}<.01$, this suggests that at stage 2 there is a positive relationship between the number of new devices and the number of new adopters.

Considering stage 1 and 2 as the two earliest stages, the results support that there is a positive relation between entry rate of new mobile devices and the entry rate of new adopters. Therefore, hypothesis $2 \mathrm{a}$ is supported.

\subsubsection{Hypothesis 2b: At latter stages, the entry rate of new devices is negatively related to the entry rate of new adopters}

The results obtained for testing hypothesis $2 \mathrm{~b}$ are shown on Appendix 5. At stage 3, the latter adoption stage of the study, the Spearman correlation coefficient for new mobile devices and new adopters is 0.895 with sig. of 0.000 . Given that the coefficient is positive and significant at $p<.01$, this suggests that at stage 3 there is a positive relationship between the number of new devices and the number of new adopters. Hypothesis $2 b$ is not supported.

\subsection{Hypothesis 3}

\subsubsection{Hypothesis 3a: The type of device is a function of adoption stage}

Table 20 shows the results of the multiple comparisons between stages using the MannWhitney $\mathrm{U}$ test. In addition, Appendix 6 contains the results for the tests. 
Table 20: Mann-Whitney $U$ test comparisons for types of mobile device launched 57 mobile devices launched

\begin{tabular}{|l|l|l|l|l|}
\hline Product diversity & N & Mean Rank & Sum of & Asymp. Sig. (2-tailed) \\
& & & ranks & \\
\hline Stage 1 & 12 & 15.88 & 190.50 & .948 \\
Stage 2 & 19 & 16.08 & 305.50 & \\
\hline Stage 1 & 12 & 18.88 & 226.50 & .792 \\
Stage 3 & 26 & 19.79 & 514.50 & \\
\hline Stage 2 & 19 & 22.34 & 424.50 & .763 \\
\hline
\end{tabular}

The results on Table 20 show that there is no significant association between the type of new device and the stage of adoption. Hypothesis $3 \mathrm{a}$ is not supported.

\subsubsection{Hypothesis 3b: At early stages, product diversity is high}

In order to test hypothesis $3 b$ and $3 c$, the normality of the distribution of product diversity needs to be determined at each adoption stage. Table 21 shows the descriptive statistics for product diversity per adoption stage. 
Table 21: Descriptive statistics for product diversity per adoption stage

\begin{tabular}{|c|c|c|c|c|c|c|c|c|c|}
\hline \multirow{2}{*}{$\begin{array}{l}\text { Adoption } \\
\text { stage }\end{array}$} & \multirow[t]{2}{*}{$\mathbf{N}$} & \multirow[t]{2}{*}{ Min } & \multirow[t]{2}{*}{$\operatorname{Max}$} & \multirow[t]{2}{*}{ Mean } & \multirow{2}{*}{$\begin{array}{l}\text { Std. } \\
\text { dev. }\end{array}$} & \multicolumn{2}{|c|}{ Skewness } & \multicolumn{2}{|l|}{ Kurtosis } \\
\hline & & & & & & Statistic & $\begin{array}{l}\text { Std. } \\
\text { error }\end{array}$ & Statistic & $\begin{array}{l}\text { Std. } \\
\text { error }\end{array}$ \\
\hline & 48 & & & & & & .3 & & .674 \\
\hline & 1 & & & & & & .597 & & 1.154 \\
\hline Stage 3 & 12 & .6667 & .6924 & .6815 & 0.0095 & -.573 & .637 & -1.458 & 1.232 \\
\hline
\end{tabular}

The statistics presented on Table 21 showed that product diversity is not normally distributed for all stage 1. As a result, for comparisons examining the association of product diversity and adoption the Mann-Whitney $U$ test was used. Appendix 7 contains the table of test results.

Table 22: Mann-Whitney $U$ test for comparisons for product diversity

\begin{tabular}{|l|l|l|l|l|}
\hline Product diversity & $\mathrm{N}$ & Rank sum & Mean rank & Asymp. Sig. (2-tailed) \\
\hline Stage 1 & 48 & 25.73 & 1235.00 & .000 \\
Stage 2 & 14 & 51.29 & 718.00 & \\
\hline Stage 1 & 48 & 24.50 & 1176.00 & .000 \\
Stage 3 & 12 & 54.50 & 654.00 & \\
\hline Stage 2 & 14 & 7.86 & 110.00 & .000 \\
Stage 3 & 12 & 20.08 & 241.00 & \\
\hline
\end{tabular}


The results displayed in Table 22 show that mean rank is significant between every two stages at $\mathrm{p}<.10$. In addition, the results on Table 21 show that product diversity at stage 1 , the earliest stage, is considerably larger than the ones at stages 2 and 3 . Furthermore, product diversity at stage 2 , the second earliest stage, is higher than the one at stage 3 , however the increase is considerably lower to that between stage 1 and stage 2 . As a result hypothesis $3 \mathrm{~b}$ is supported.

\subsubsection{Hypothesis 3c: At latter stages, product diversity is low}

The results on Table 21 show that product diversity at stage 3, the latest stage, is higher than the one at stage 2. Moreover, the increase between stage 2 and 3 is lower than at the rest of the stages. As a result, hypothesis $3 \mathrm{c}$ is supported.

\subsubsection{Hypothesis 3d: The type of functions featured by devices with Linux as the EOS is a function of adoption stage}

In order to test hypothesis $3 \mathrm{~d}$, the functions featured for each mobile device were classified and codified using the method described in 4.7.4. Appendix 8 provides the descriptive statistics for the number of functions featured by adoption stage.

The Chi-square test was used to test hypothesis $3 \mathrm{~d}$. Table 23 shows the contingency table and the results of the Chi-square test for the association between type of functions featured and adoption stage. 
Table 23: Contingency table for type of functions featured per adoption stage

Contingency table (cells provide counts)

\begin{tabular}{|l|c|c|c|c|}
\hline Type of function & Stage 1 & Stage 2 & Stage 3 & Total \\
\hline Traditional cellular communication & 101 & 144 & 179 & 424 \\
\hline Additional voice/data communication & 65 & 88 & 117 & 270 \\
\hline Information management & 134 & 110 & 181 & 425 \\
\hline Entertainment & 81 & 134 & 147 & 362 \\
\hline Total & 381 & 476 & 624 & 1481 \\
\hline
\end{tabular}

Table 24 shows the Chi-square test for the association between type of functions featured and adoption stage.

Table 24: Chi-square test for type of functions featured per adoption stage

Adoption stage * Function type cross tabulation

\begin{tabular}{|l|l|l|l|l|l|}
\hline \multirow{2}{*}{$\begin{array}{l}\text { Adoption } \\
\text { stage }\end{array}$} & \multicolumn{3}{|c|}{ Function type } & Total \\
\cline { 2 - 5 } & $\begin{array}{l}\text { Traditional } \\
\text { cellular } \\
\text { communication }\end{array}$ & $\begin{array}{l}\text { Additional } \\
\text { voice/data } \\
\text { communication }\end{array}$ & $\begin{array}{l}\text { Information } \\
\text { management }\end{array}$ & Entertainment & \\
\hline $\begin{array}{l}\text { Stage 1 } \\
\text { Count }\end{array}$ & 101 & 65 & 134 & 81 & 381 \\
\hline Expected & 109.1 & 69.5 & 109.3 & 93.1 & 381.0 \\
\hline $\begin{array}{l}\text { Stage } 2 \\
\text { Count }\end{array}$ & 144 & 88 & 110 & 134 & 476 \\
\hline Expected & 136.3 & 86.8 & 136.6 & 116.3 & 476.0 \\
\hline $\begin{array}{l}\text { Stage 3 } \\
\text { Count }\end{array}$ & 179 & 117 & 181 & 147 & 624 \\
\hline Expected & 178.6 & 113.8 & 179.1 & 152.5 & 624.0 \\
\hline $\begin{array}{l}\text { Total } \\
\text { Count }\end{array}$ & 424 & 270 & 425 & 362 & 1481 \\
\hline Expected & 424.0 & 270.0 & 425.0 & 362.0 & 1481.0 \\
\hline
\end{tabular}




\section{Chi-square test results}

\begin{tabular}{|l|c|c|c|}
\hline & Value & df & Asymp. Sig. (2-sided) \\
\hline Pearson Chi-Square & $16.654(\mathrm{a})$ & 6 & .011 \\
\hline Likelihood Ratio & 16.613 & 6 & .011 \\
\hline Linear-by-Linear Association & .165 & 1 & .685 \\
\hline N of Valid Cases & 1481 & & \\
& & & \\
\hline
\end{tabular}

a. 0 cells $(.0 \%)$ have expected count less than 5 . The minimum expected count is 69.46 .

The results on Table 24 show that there is a significant association between the type of functions featured and the adoption stage. Hypothesis $3 \mathrm{~d}$ is supported.

\section{$5.8 \quad$ Hypothesis 4}

\subsubsection{Hypothesis 4a: The reasons for partnership formation are a function of adoption stage}

The Chi-square test was used to test hypothesis $4 \mathrm{a}$. Table 25 shows the contingency table and the results of the Chi-square test for the association between type of new device and adoption stage. 
Table 25: Contingency table for reasons for partnership formation per adoption stage

Contingency table (cells provide counts)

\begin{tabular}{|l|l|l|l|l|}
\hline $\begin{array}{l}\text { Reasons for } \\
\text { partnership } \\
\text { formation }\end{array}$ & Stage 1 & Stage 2 & Stage 3 & Total \\
\hline Product related & 24 & 4 & 4 & 32 \\
\hline $\begin{array}{l}\text { Market / } \\
\text { industry related }\end{array}$ & 13 & 11 & 10 & 34 \\
\hline $\begin{array}{l}\text { Technology } \\
\text { related }\end{array}$ & 23 & 13 & 12 & 48 \\
\hline
\end{tabular}

Table 26 shows the Chi-square test for the association between reasons for adoption and adoption stage. 
Table 26: Chi-square test for reasons for partnership formation per adoption stage

Adoption stage * Reasons for partnership formation cross tabulation

\begin{tabular}{|l|c|c|c|c|}
\hline \multirow{2}{*}{ Adoption stage } & \multicolumn{3}{|c|}{ Reasons for partnership formation } & \multirow{2}{*}{ Total } \\
\cline { 2 - 5 } & $\begin{array}{l}\text { Product } \\
\text { related }\end{array}$ & $\begin{array}{l}\text { Market } \\
\text { industry } \\
\text { related }\end{array}$ & $\begin{array}{l}\text { Technology } \\
\text { related }\end{array}$ & \\
\hline $\begin{array}{l}\text { Stage1 } \\
\text { Count }\end{array}$ & 24 & 13 & 23 & 60 \\
\hline Expected & 16.8 & 17.9 & 25.3 & 60.0 \\
\hline $\begin{array}{l}\text { Stage 2 } \\
\text { Count }\end{array}$ & 4 & 11 & 13 & 28 \\
\hline Expected & 7.9 & 8.4 & 11.8 & 28.0 \\
\hline $\begin{array}{l}\text { Stage 3 } \\
\text { Count }\end{array}$ & 4 & 10 & 12 & 26 \\
\hline Expected & 7.3 & 7.8 & 10.9 & 26.0 \\
\hline $\begin{array}{l}\text { Total } \\
\text { Count }\end{array}$ & 32 & 34 & 48 & 114 \\
\hline Expected & 32.0 & 34.0 & 48.0 & 114.0 \\
\hline
\end{tabular}

\section{Chi-square test results}

\begin{tabular}{|l|c|c|c|}
\hline & Value & df & Asymp. Sig. (2-sided) \\
\hline Pearson Chi-Square & $9.686(\mathrm{a})$ & 4 & .046 \\
\hline Likelihood Ratio & 10.053 & 4 & .040 \\
\hline Linear-by-Linear Association & 3.634 & 1 & .057 \\
\hline N of Valid Cases & 114 & & \\
\hline
\end{tabular}

a. 0 cells $(.0 \%)$ have expected count less than 5 . The minimum expected count is 7.30 .

The results on Table 26 show that there is a significant association between the reasons for partnership formation and the stage of adoption. Hypothesis $4 \mathrm{a}$ is supported. 


\subsubsection{Hypothesis 4b: The type of partner is a function of adoption stage}

The Chi-square test was used to test hypothesis $4 \mathrm{~b}$. Table 27 shows the contingency table and the results of the Chi-square test for the association between type of partner and adoption stage.

Table 27: Chi-square test for the association of type of partner

\section{Contingency table (cells provide counts)}

\begin{tabular}{|c|c|c|c|c|c|}
\hline & \multicolumn{4}{|c|}{ Type of partner } & \\
\cline { 1 - 5 } $\begin{array}{l}\text { Adoption } \\
\text { stage }\end{array}$ & Competitor & Supplier & $\begin{array}{l}\text { Service } \\
\text { provider }\end{array}$ & $\begin{array}{l}\text { Industry } \\
\text { consortium }\end{array}$ & Total \\
\hline 1 & 12 & 11 & 1 & 2 & 26 \\
\hline 2 & 4 & 20 & 5 & 4 & 33 \\
\hline 3 & 5 & 4 & 6 & 3 & 18 \\
\hline Total & 21 & 35 & 12 & 9 & 77 \\
\hline
\end{tabular}

\section{Chi-square test results}

\begin{tabular}{|l|c|c|c|}
\hline & Value & df & Asymp. Sig. (2-sided) \\
\hline Pearson Chi-Square & $16.722(\mathrm{a})$ & 6 & .010 \\
\hline Likelihood Ratio & 17.316 & 6 & .008 \\
\hline Linear-by-Linear Association & 5.779 & 1 & .016 \\
\hline N of Valid Cases & 77 & & \\
\hline
\end{tabular}

a. 6 cells $(50.0 \%)$ have expected count less than 5 . The minimum expected count is 2.10 .

From the results of Table 27, six cells have an expected count of less than 5 . Therefore, in order to comply with the requirements of a Chi-square test, the type of partners were consolidated in two groups: competitor and industry consortium; and supplier and service 
provider. A second Chi-Square test was performed using these two groups. Table 28 shows the results of the second Chi-Square test.

Table 28: Chi-square second test for the association of type of partner

Contingency table (cells provide counts)

\begin{tabular}{|c|l|c|c|}
\hline & \multicolumn{2}{|c|}{ Type of partner } & \\
\cline { 1 - 1 } $\begin{array}{l}\text { Adoption } \\
\text { stage }\end{array}$ & $\begin{array}{l}\text { Competitor / Industry } \\
\text { consortium }\end{array}$ & Supplier / Service provider & Total \\
\hline 1 & 14 & 12 & 26 \\
\hline 2 & 8 & 25 & 33 \\
\hline 3 & 8 & 10 & 18 \\
\hline Total & 30 & 47 & 77 \\
\hline
\end{tabular}

\section{Chi-square test results}

\begin{tabular}{|l|c|c|c|}
\hline & Value & df & Asymp. Sig. (2-sided) \\
\hline Pearson Chi-Square & $5.656(\mathrm{a})$ & 2 & .059 \\
\hline Likelihood Ratio & 5.785 & 2 & .055 \\
\hline Linear-by-Linear Association & .779 & 1 & .371 \\
\hline N of Valid Cases & 77 & & \\
\hline
\end{tabular}

a. 0 cells $(.0 \%)$ have expected count less than 5 . The minimum expected count is 7.01 .

The Chi-Square test results show that the association between rows and columns was significant at .059 not $\mathrm{p}<.05$. Therefore, these results show that there is no significant association between the type of partner and the stage of adoption. Hypothesis $4 \mathrm{~b}$ is not supported. 


\subsubsection{Hypothesis 4c: The number of partnerships with competitors and industry consortiums are positively related to the adoption of new mobile devices}

In order to measure the impact of partnerships with competitors and consortia on the launch of new mobile devices, the cumulative number of such partnerships for the previous three months was calculated for each month of the study period. From the descriptive statistics in 5.2.1 we know that the entry of new devices is not normally distributed, therefore a Spearman correlation test was used.

The Spearman correlation coefficient for the number of new mobile devices per month and the cumulative number of partners with competitors and industry consortia for the previous three months is 0.342 with sig. of 0.003 , two tailed test. Given that the coefficient of the test is positive and significant at $\mathrm{p}<.01$, the results suggest that there is a positive relationship between the number of partnerships with competitors and industry consortia and the entry of new mobile devices. Appendix 9 shows a table with detailed results. Hypothesis $4 \mathrm{c}$ is supported.

\subsection{Summary of results of testing hypotheses}

Table 29 provides a summary of the results of testing hypotheses. 
Table 29: Summary of results of testing hypotheses

\begin{tabular}{|l|l|l|}
\hline Hypothesis & $\begin{array}{l}\text { Supported } \\
\text { or not } \\
\text { supported }\end{array}$ & Rationale \\
\hline $\begin{array}{l}\text { Hypothesis 1: The reasons for } \\
\text { the adoption of Linux are a } \\
\text { function of the adoption stage }\end{array}$ & $\begin{array}{l}\text { Not } \\
\text { supported }\end{array}$ & $\begin{array}{l}\text { The results of the Chi-square test show } \\
\text { that the association between reasons for } \\
\text { adoption and adoption stage is not } \\
\text { significant at } \mathbf{p}<.05\end{array}$ \\
\hline $\begin{array}{l}\text { Hypothesis 2a: At early } \\
\text { stages, the entry rate of new } \\
\text { devices is positively related to } \\
\text { the entry rate of new adopters }\end{array}$ & Supported & $\begin{array}{l}\text { The Spearman correlation coefficient } \\
\text { for new mobile devices and new } \\
\text { adopters is positive and significant at } \\
\mathbf{p}<.01 \text { for stages 1 and 2 }\end{array}$ \\
\hline $\begin{array}{l}\text { Hypothesis 2b: At latter } \\
\text { stages, the entry rate of new } \\
\text { devices is negatively related to } \\
\text { the entry rate of new adopters }\end{array}$ & supported & $\begin{array}{l}\text { The Spearman correlation coefficient } \\
\text { for new mobile devices and new } \\
\text { adopters is positive and significant at } \\
\text { p<.01 for stage 3 }\end{array}$ \\
\hline $\begin{array}{l}\text { Hypothesis 3a: } \text { The type of } \\
\text { device is a function of } \\
\text { adoption stage }\end{array}$ & $\begin{array}{l}\text { Not } \\
\text { supported }\end{array}$ & $\begin{array}{l}\text { The Mann-Whitney U test results show } \\
\text { that the association between type of } \\
\text { device and adoption stages is not } \\
\text { significant at p<.10 }\end{array}$ \\
\hline $\begin{array}{l}\text { Hypothesis 3b: At early } \\
\text { stages, product diversity is } \\
\text { high }\end{array}$ & $\begin{array}{l}\text { The Mann-Whitney U test results show } \\
\text { that the association between product } \\
\text { diversity and adoption stages } \\
\text { significant at p<.10 In addition, } \\
\text { product diversity at stages 1 and 2 is } \\
\text { higher than that at stage 3 }\end{array}$ \\
\hline
\end{tabular}




\begin{tabular}{|c|c|c|}
\hline $\begin{array}{l}\text { Hypothesis 3c: At latter } \\
\text { stages, product diversity is low }\end{array}$ & Supported & $\begin{array}{l}\text { The Mann-Whitney } \mathrm{U} \text { test results show } \\
\text { that the association between product } \\
\text { diversity and adoption stages } \\
\text { significant at } \mathrm{p}<.10 \text { In addition, product } \\
\text { diversity at stage } 3 \text { is lower than at the } \\
\text { rest of the stages }\end{array}$ \\
\hline $\begin{array}{l}\text { Hypothesis 3d: The type of } \\
\text { functions featured by devices } \\
\text { with Linux as the EOS is a } \\
\text { function of adoption stage }\end{array}$ & Supported & $\begin{array}{l}\text { The results of the Chi-square test show } \\
\text { that the association between reasons for } \\
\text { adoption and adoption stage is } \\
\text { significant at } p<.05\end{array}$ \\
\hline $\begin{array}{l}\text { Hypothesis 4a: The reasons } \\
\text { for partnership formation are a } \\
\text { function of adoption stage }\end{array}$ & Supported & $\begin{array}{l}\text { The results of the Chi-square test show } \\
\text { that the association between reasons for } \\
\text { partnership formation and adoption } \\
\text { stage is significant at } \mathrm{p}<.05\end{array}$ \\
\hline $\begin{array}{l}\text { Hypothesis 4b: The type of } \\
\text { partner is a function of } \\
\text { adoption stage }\end{array}$ & $\begin{array}{l}\text { Not } \\
\text { supported }\end{array}$ & $\begin{array}{l}\text { The results of the Chi-square test show } \\
\text { that the association between type of } \\
\text { partner and adoption stage is not } \\
\text { significant at } p<.05\end{array}$ \\
\hline $\begin{array}{l}\text { Hypothesis 4c: The number of } \\
\text { partnerships with competitors } \\
\text { and industry consortia are } \\
\text { positively related to the } \\
\text { adoption of new mobile } \\
\text { devices }\end{array}$ & Supported & $\begin{array}{l}\text { The Spearman correlation coefficient } \\
\text { for the number of new mobile devices } \\
\text { and the number of partnerships with } \\
\text { competitors and industry consortia is } \\
\text { positive and significant at } p<.01\end{array}$ \\
\hline
\end{tabular}




\section{DISCUSSION OF RESULTS}

\subsection{Answer to the four research questions}

The objective of this research was to answer four research questions relevant to the adoption of Linux as the EOS in converged mobile devices.

\section{What are the reasons to adopt Linux?}

The results on Table 16 show the main reason for adoption is the Linux compatibility. Triability was the second most common reason for adoption, and relative advantage was the third.

This researcher expected the reasons for adoption to change across adoption stages. However, the test results on Table 17 show that there is no association between changes in reasons for adoption and adoption stages. Moreover, the results suggest that the reasons for adopting Linux as the EOS were almost constant across the 74 month duration of the study period.

What is the relationship between entry rate of new converged mobile devices with Linux as the EOS and the entry rate of new adopters over time?

The results of testing hypothesis $2 \mathrm{a}$ are shown in Appendix 5. These results suggest that the entry rate of new mobile devices was positively related to the entry rate of new adopters during the study period. 
The results of testing hypothesis $2 \mathrm{~b}$ are shown in Appendix 5. These results suggest that during the latter stage of adoption, the relationship between entry rate of new devices and the entry rate of new adopters remains positive.

How do the characteristics of the devices that adopted Linux as the EOS and product diversity change across adoption stages?

This study examined three characteristics: the type of device, product diversity and the type of functions featured in mobile devices. The results in Table 20 show that there is no significant association between the type of mobile device launched and adoption stages.

The results in Table 22 suggest that product diversity was considerably different across adoption stages. The descriptive statistics shown on Table 21 show that the standard deviation on product diversity is considerably lower at the third stage than the previous two.

The results on Table 24 show that the type of functions featured by mobile devices is a function of adoption stage.

\section{How do partnerships affect the adoption of Linux?}

This research examined three aspects of partnerships: the reasons for partnership formation, the type of partner selected, and the relationship between partnerships among competitors and industry consortia and the entry rate of new devices. 
The results shown in Table 26 suggest that there is a relationship between the reasons for partnership formation and adoption stage. During stage 1 , the reasons for partnership formation were product and technology related. During stages 2 and 3 , the reasons for partnership formation were technology and market/industry related.

The results on Table 28 show that the type of partner selected is not a function of adoption stage.

The results on Appendix 9 suggest that the number of partnerships among competitors and industry consortia is positively related to the entry rate of new devices.

\subsection{Discussion}

\subsubsection{Reasons for adoption of Linux as the EOS in mobile devices}

The results of this research suggest that the main reasons to adopt Linux as the EOS in converged mobile devices are compatibility, triability and relative advantage. These findings differ slightly from the main reasons to adopt of Linux as server operating platform as reported by Dedrick and West (2004). They found that relative advantage, compatibility and reduced complexity were the most valued characteristics perceived by adopters of Linux at a platform level.

The results of this research suggest Linux is more appreciated by mobile device manufacturers for its triability, or the degree to which they might experiment with it. This 
differs from server platform level adopters who choose Linux because they find it less difficult to use and understand.

The reasons to adopt Linux as the EOS in mobile devices did not change during the study period. This differs from the results reported by Napoles (2005). He concluded that there was an association between the adoption stage and the reasons for which buyers and suppliers adopted UML based development tools.

\subsubsection{Rate of adoption of Linux, entry rate of new devices and new adopters}

Figure 3 and Tables 13 and 14 show that the rate of adoption of Linux by mobile device manufacturers was low at the start and then increased over time. This observation is consistent with the theory of adoption and diffusion (Rogers, 1983). At the beginning, only a small group of innovators adopted Linux. The data displayed on Tables 12 and 13 shows that during the first 48 months of the study Linux had been adopted by only 12 mobile devices. This means that only 21 percent of the observed mobile devices had been launched with Linux as the EOS during nearly the first two-thirds of the study, from October 2000 to September 2004.

Throughout the following 14 months, the adoption of Linux started to rise, with 19 new mobile devices with Linux as the EOS launched in this period. Moore (1991) describes this phenomenon as crossing the "chasm" and the emergence of the mainstream market. On 2006, the rate of adoption increased considerably with more than 45 percent of the 
mobile devices in the sample launched during that year. A total of 26 new converged mobile devices with embedded Linux were launched across these 12 months alone.

The density-dependence model has been used in previous research studies to relate the population density of a system with the number of new arrivals (Debackere et al., 1998). At an early period, the population density is expected to be positively related to the entry rate of new adopters. Whereas, when population density reaches a critical level it becomes negatively related to the entrance of new adopters. Previous examinations of adoption processes by Peng (2004), Napoles (2005) and Ali (2005) have reported similar patterns. They have found that at early stages the entry of new adopters increases reaching a critical level and then slows down at latter stages.

The test results obtained show that the entry rate of new devices is positively related to the entry rate of new adopter across the three adoption stages identified for this research. Even during the latter adoption stage the entry rate of new devices was positively related to the entry rate of new adopters. These results suggest that the density of new devices has not yet reached a critical level. Moreover according to the observations by Geroski (2000), these results could mean that the adoption of Linux as the EOS in mobile devices is still in the legitimization period.

Geroski (2000) and results reported by Peng (2004), Ali (2005) and Napoles (2005) suggest that the adoption process will reach a critical level entering the competition 
period. During this period, the density of converged mobile devices in the market is expected to be negatively related to the entry rate of new adopters.

\subsubsection{Characteristics and product diversity of mobile devices with Linux as the EOS}

The results in Table 20 suggest that the type of product launched is not related to adoption stages and that nearly half of the mobile devices launched were information management type.

The test results on Table 22 suggest that changes in product diversity are significantly different across adoption stages. Results reported by Peng (2004), Napoles (2005) and Ali (2005) indicate that they examined innovation legitimization and competition periods (Geroski, 2000). However, the finding that entry rate and new adopters are positively related suggests that the process of adoption of Linux as the EOS for converged mobile devices is still in a legitimization period.

Gerosky (2000) sustained that the choices made at a legitimization period amongst the possible variants may have an extremely powerful effect on the path of diffusion. The results displayed on Table 24 suggest that the type of functions featured by new mobile devices is a function of adoption stage. Moreover, the data on Table 23 shows that at the first stage of adoption the functions featured were mostly of the information management type. At the second stage of adoption, the mobile devices featured mostly traditional cellular communication functions and entertainment functions. Finally, at the third stage 
of adoption, most functions featured were information management and traditional cellular communication functions. These results suggest that future new adopters of Linux for converged mobile devices might choose to include mainly information management and traditional cellular functions, following the steps early adopters have taken.

\subsubsection{Partnerships and the adoption of Linux as the EOS in mobile devices}

The results on Table 26 show that there is a relationship between the reasons for partnership formation and the stage of adoption. This result is contrary to the findings by Peng (2004) in the case of adoption of Linux by firms. The data on Table 25 show that during the first stage of adoption most partnerships were formed for product related and technology related motives. Mobile device manufacturers at this stage looked for partners to add value to their products and to solve technological issues related to Linux. During the second and third adoption stages, the most common motives for partnership formation were technology related and market and industry related. While technological improvements were still a concern for mobile device manufacturers, they also started to look for partners for the purpose of commercializing and positioning their products, as well as industry allies to promote the emergence of a standard for embedded Linux.

The results on Tables 27 and 28 show that there is no significant association between the type of partner selected and adoption stages. 
This research found that partnerships with competitors and industry consortia were positively related to the adoption of Linux as the EOS in mobile devices. The results reported on Appendix 9 show that there is a significant association between the number of new devices launched in a month and the number of partnerships that mobile device manufacturers established with competitors and industry consortium in that same quarter. This result suggests that the alliances between direct competitors and industry consortia have helped Linux to gain legitimacy as the EOS in converged mobile devices. 


\section{CONCLUSION, LIMITATION AND FUTURE RESEARCH}

\subsection{Conclusions}

An increasing number of companies are adopting Linux as the EOS for mobile devices. The attributes of compatibility and triability keep attracting mobile device manufacturers to adopt Linux as the EOS in their products. The fact that the population density is still positively related to the number of new entrants suggests that the adoption process has not yet reached a critical level. This finding suggests that this innovation has not reached the competition period in this particular market.

In terms of partnerships, mobile device manufacturers have established partnerships among competitors and industry consortia to propel the adoption of Linux. Moreover, the results of this research show that these partnerships have had a positive impact on the number of devices launched.

The results show that the reasons for partnership formation follow a temporal pattern. At the beginning of the adoption process, the main concern is to add value to the products offered. However, during the latter part of the study period, the motives for partnership formation are more focused on a better market positioning of the products and finding industry partners in an effort to reach a standard for embedded Linux. Mobile device manufacturers that have adopted Linux are following similar moves to those taken in the past by companies behind proprietary developments such as Bluetooth and Symbian. 
The findings reported on this research provide managers with useful arguments for the decision-making process towards their involvement on businesses related to Linux for converged mobile devices. This research provides managers an identification of mobile device manufacturers involved in Linux; it reveals the current stage reached in the adoption life cycle of Linux as the EOS; it provides insights on market trends with the classification by type of functions featured by adopting devices; and it highlights the importance of partnerships in the adoption process. All these elements are especially useful to managers deciding on the adoption of Linux as the EOS, the development of a Linux compatible application for converged mobile devices, or the design of a Linux compatible service for mobile telecommunication service providers.

Finally, this research shows that the method designed by Peng (2004) for the identification of adoption stages can provide insights on the adoption of a technological innovation within a specific market segment.

\subsection{Limitations}

Language differences may have hidden details that could have provided richer insights to this research.

This research used publicly available information. Thus, it suffers from all the limitations typically attributed to the use of such data. Discussion of results with top management teams could provide richer insights than those discussed here. 
This research focused on the adoption of Linux as the EOS of mobile devices by commercial for-profit firms. It did not compare the adoption of Linux in other devices.

\subsection{Suggestions for future research}

Future research can evaluate the development of Linux compatible complementary applications for mobile devices and the emergent market of user-customizable Linux based services.

The results of this research can be used to make predictions and then examine the accuracy of these predictions.

The actions of mobile telecommunication service providers undertaken to motivate the adoption of Linux EOS across geographical regions could provide insights to both common and unique practices. 


\section{REFERENCES}

Alam, R. 2005. Open source projects, market offers and competitive advantage. Master's Thesis, Carleton University

Bonnaccorsi, A., Rossi, C. 2003. Why open source software can succeed? Research Policy, 32(7): 1243-1258

Bowman, C., Ambrosini, V. 2000. Value creation versus value capture: towards a coherent definition of value in strategy. British Journal of Management, 11: 1-15

Chau, P. Y. K., Tam, K. Y. 1997. Factors affecting the adoption of open systems: an exploratory study. MIS Quarterly, 21(1): 1-24

Debackere, K., Clarysse, B. 1998. Advanced bibliometric methods to model the relationship between entry behavior and networking in emerging technological communities. Journal of the American Society for Information Science, 49(1): 49-58

Dedrick, J., West, J. 2004. An exploratory study into open source platform adoption. Proceedings of the 37th Annual Hawaii International Conference on System Sciences HICSS'04: 1-10

DiMaggio, P. J., Powell, W. W. 1983. The iron cage revisited: institutional isomorphism and collective rationality in organizational fields. American Sociological Review, 48(2): $147-160$

Dodourova, M. 2003. Industry dynamics and strategic positioning in the wireless telecommunications industry: the case of Vodafone Group. Management Decision, 41(9): 859-870

Franke, N., von Hippel, E. 2003. Satisfying heterogeneous user needs via innovation toolkits: the case of Apache security software. Research Policy, 32(7): 1199-1215

Garrard, G.A. 1998. Cellular communications: Worldwide market development. Artech House, Boston

Geroski, P. A. 2000. Models of technology diffusion. Research Policy, 29(4/5): 603-625

Grant, R. M. 1996. Toward a knowledge-based theory of the firm. Strategic

Management Journal, 17(winter special issue): 109-122

Grand, S., von Krogh, G., Leonard D., Swap, W. 2004. Resource allocation beyond firm boundaries: A multi-level model for open source innovation. Long Range Planning, 37(6): 591-610 
Gulati, R. 1995. Social structure and alliance formation patterns: a longitudinal analysis. Administrative Science Quarterly, 40(4): 619-652

Hamel, G. 1991. Competition for competence and inter-partner learning within international strategic alliances. Strategic Management Journal, 12(4): 83-103

Hennart, J. F. 1988. A transaction costs theory of equity joint ventures. Strategic Management Journal, 9(4): 361-374

Hennart, J. F. 1991. The transaction costs theory of joint ventures: an empirical study of Japanese subsidiaries in the United States. Management Science, 37(4): 483-497

Khanna, T., Gulati, R., Nohria, N. 1998. The dynamics of learning alliances: competition, cooperation, and relative scope. Strategic Management Journal, 19(3): 193-210

Keil, T. 2002. De-facto standardization through alliances-lessons from Bluetooth. Telecommunications Policy, 26(3/4): 205-213

Koch, S., Schneider, G. 2002. Effort, co-operation and co-ordination in an open source software project: GNOME. Information Systems Journal, 12(1): 27-42

Kogut, B., Metiu, A. 2001. Open-source software development and distributed innovation. Oxford Review of Economic Policy, 17(2): 248-264

Koru, A.G., Tian, J. 2004. Defect handling in medium and large open source projects. IEEE Software, 21(4): 54-61

Lerner, J., Tirole, J. 2002. Some simple economics of open source. Journal of Industrial Economics, 50(2): 197-234

Markus, M. L., Manville, B., Agres, C. E. 2000. What makes a virtual organization work? MIT Sloan Management Review, 42(1): 13-26

Microsoft Corporation. 2007. Microsoft Windows Mobile-Smartphone and pocket PC software with ActiveSync. http://www.microsoft.com/windowsmobile/ (accessed April $21,2007)$

Moore, G. A. 1991. Crossing the chasm: marketing and selling high-tech products to mainstream customers. Harper Business, New York

Mowery, D. C., Oxley, J. E., Silverman, B. S. 1996. Strategic alliances and interfirm knowledge transfer. Strategic Management Journal, 17(winter special issue): 77-91

Mustonen, M. 2005. When does a firm support substitute open source programming? Journal of Economics \& Management Strategy, 14(1): 121-139 
Napoles, R. 2005. Evolution and adoption of UML-based development tools. Master's Thesis, Carleton University

O'Mahony, S. 2003. Guarding the commons: how community managed software projects protect their work. Research Policy, 32(7): 1179-1198

Oshri, I., Weeber, C. 2006. Cooperation and competition standards-setting activities in the digitalization era: the case of wireless information devices. Technology Analysis \& Strategic Management, 18(2): 265-283

Peng, Z. 2004. Linux adoption by firms. Master's Thesis, Carleton University

Pfeffer, J., Nowak, P. 1976. Joint ventures and interorganizational interdependence. Administrative Science Quarterly, 21(3): 398-418

Porter M.E. 1983. Cases in competitive strategy. Free Press. New York

Rehman, R. 2006. Factors that Contribute to Open Source Software Project Success. Master's Thesis, Carleton University

Rogers, E. M. 1983. Diffusion of innovations. Third edition, Free Press, New York

Stewart, K.J., Ammeter, A.P., Maruping, L.M. 2005. A preliminary analysis of the influences of licensing and organizational sponsorship on success in open source projects. Proceedings of the 38th Annual Hawaii International Conference on System Sciences, HICSS '05: 197c-197

Symbian. 2007. Symbian OS - The mobile operating system. http://www.symbian.com (Accessed April 21, 2007)

Tornatsky, L. G., Klein, K. J. 1982. Innovation characteristics and innovation adoption implementation. IEEE Transactions on Engineering Management, 29: 28-45.

Välimäki, M., Oksanen, V. 2005. The impact of free and open source licensing on operating system software markets. Telematics and Informatics, 22(1-2): 97-110

von Hippel, E., von Krogh, G. 2003. Open source software and the 'private-collective' innovation model: issues for organization science. Organization Science, 14(2): 209-223

West, J., O'Mahony, S. 2005. Contrasting community building in sponsored and community founded open source projects. Proceedings of the 38th Annual Hawaii International Conference on System Sciences HICSS '05: 196c-196c

Williamson, O. E. 1991 .Comparative economic organization: the analysis of discrete structural alternatives. Administrative Science Quarterly, 36(2): 269-296 


\section{Appendix 1: Motives for alliance formation}

\begin{tabular}{|c|c|}
\hline Motives & Description \\
\hline Market-related motives & $\begin{array}{l}\text { Gain access to new markets, create and experiment with new } \\
\text { markets, circumvent legal, regulatory, or other barriers, } \\
\text { defend/enhance market position in present markets }\end{array}$ \\
\hline Product-related motives & $\begin{array}{l}\text { Create and experiment with new products, broaden/fill gaps } \\
\text { in present product line, differentiate/enter new product } \\
\text { domains, add value to a product, property rights protection }\end{array}$ \\
\hline $\begin{array}{l}\text { Industry/market structure } \\
\text { modification-related } \\
\text { motives }\end{array}$ & $\begin{array}{l}\text { Reduce (potential) competition, raise entry barriers, alter the } \\
\text { technological base of competition }\end{array}$ \\
\hline Timing-related motives & $\begin{array}{l}\text { Experiment with new product/market/technology } \\
\text { opportunities faster by accelerating pace of R\&D or market } \\
\text { entry }\end{array}$ \\
\hline Cost-related motives & $\begin{array}{l}\text { Lower R\&D/manufacturing/marketing/organizational costs, } \\
\text { achieve economies of scale }\end{array}$ \\
\hline $\begin{array}{l}\text { Risk reduction - related } \\
\text { motives }\end{array}$ & $\begin{array}{l}\text { Lower risk in the face of large } \mathrm{R} \& \mathrm{D} \text { costs required, } \\
\text { technological/market or other uncertainties }\end{array}$ \\
\hline $\begin{array}{l}\text { Competencies and skills- } \\
\text { related motives }\end{array}$ & $\begin{array}{l}\text { Overcome shortcomings in internal competencies; Internalize } \\
\text { competencies, enhance knowledge-generation activities, } \\
\text { learn new skills, enhance present skills }\end{array}$ \\
\hline $\begin{array}{l}\text { Technology-related } \\
\text { motives }\end{array}$ & $\begin{array}{l}\text { Need to experiment, gain access to technology, gain access to } \\
\text { assets that are essential for efficient commercialization of a } \\
\text { technology, exploit the potential for broad application of } \\
\text { technology, need for technical coordination/develop } \\
\text { technological standards, observe technological change but } \\
\text { remain flexible, collective protection of technological }\end{array}$ \\
\hline
\end{tabular}

Dodourova (2003) 
Appendix 2: Mobile devices launched with Linux as the EOS and cellular capabilities

\begin{tabular}{|c|c|c|c|}
\hline $\begin{array}{l}\text { Date of } \\
\text { announcement }\end{array}$ & Model & Manufacturer & Product type \\
\hline 29-Nov-2000 & Palmi & PalmPalm & Information management \\
\hline 3-Sep-2001 & Boomerang & Telepong Inc. & $\begin{array}{l}\text { Traditional cellular } \\
\text { communication }\end{array}$ \\
\hline 22-Jan-2003 & Paron MPC & $\begin{array}{l}\text { Consumer Direct } \\
\text { Link, Inc. }\end{array}$ & Information management \\
\hline 14-Mar-2003 & A760 & Motorola & Information management \\
\hline 16-Dec-2003 & e2800 & E28 & Information management \\
\hline 16-Dec-2003 & SCH-i519 & $\begin{array}{l}\text { Samsung } \\
\text { Electronics }\end{array}$ & Information management \\
\hline $11-F e b-2004$ & A768 & Motorola & Information management \\
\hline 18-Mar-2004 & E680 & Motorola & Entertainment \\
\hline 12-May-2004 & Identity GA-400B & Curitel & $\begin{array}{l}\text { Traditional cellular } \\
\text { communication }\end{array}$ \\
\hline 27-Jul-2004 & A780 & Motorola & Information management \\
\hline 20 -Aug-2004 & A768i & Motorola & Information management \\
\hline 24-Sep-2004 & $\mathrm{e} 2800+$ & E28 & Information management \\
\hline 9-Nov-2004 & Datang 3G Linux & Datang Mobile & Information management \\
\hline 18-Nov-2004 & N900iL & NEC & $\begin{array}{l}\text { Advanced voice/data } \\
\text { communication }\end{array}$ \\
\hline $25-J a n-2005$ & $\mathrm{~N} 901 \mathrm{iC}$ & NEC & Information management \\
\hline $1-F e b-2005$ & P901i & $\begin{array}{l}\text { Panasonic Mobile } \\
\text { Communications }\end{array}$ & Entertainment \\
\hline 14-Feb-2005 & C8000 Platform & Cellon International & Entertainment \\
\hline 14-Mar-2005 & N60 & Haier & $\begin{array}{l}\text { Traditional cellular } \\
\text { communication }\end{array}$ \\
\hline
\end{tabular}




\begin{tabular}{|c|c|c|c|}
\hline $\begin{array}{l}\text { Date of } \\
\text { announcement }\end{array}$ & Model & Manufacturer & Product type \\
\hline 5-Apr-2005 & Zircon A108 & Oswin Technology & Entertainment \\
\hline 18-Apr-2005 & Coolpad 858t & Yulong & Information management \\
\hline 1-Jun-2005 & Philips 968 & Philips & $\begin{array}{l}\text { Traditional cellular } \\
\text { communication }\end{array}$ \\
\hline 2-Jun-2005 & PWG-500 & G-Tek Electronics & $\begin{array}{l}\text { Traditional cellular } \\
\text { communication }\end{array}$ \\
\hline 14-Jun-2005 & E680i & Motorola & Entertainment \\
\hline 27-Jun-2005 & E895 & Motorola & $\begin{array}{l}\text { Traditional cellular } \\
\text { communication }\end{array}$ \\
\hline 28-Jun-2005 & e3 & ZTE & Entertainment \\
\hline 26-Jul-2005 & A728 & Motorola & $\begin{array}{l}\text { Traditional cellular } \\
\text { communication }\end{array}$ \\
\hline 26-Jul-2005 & A732 & Motorola & $\begin{array}{l}\text { Traditional cellular } \\
\text { communication }\end{array}$ \\
\hline 26-Jul-2005 & A910 & Motorola & $\begin{array}{l}\text { Traditional cellular } \\
\text { communication }\end{array}$ \\
\hline 6-Sep-2005 & e787 & $\begin{array}{l}\text { TCL Mobile } \\
\text { Communications }\end{array}$ & Information management \\
\hline $27-$ Oct-2005 & $\mathrm{N} 902 \mathrm{i}$ & NEC & Entertainment \\
\hline 1-Dec-2005 & P902i & $\begin{array}{l}\text { Panasonic Mobile } \\
\text { Communications }\end{array}$ & Entertainment \\
\hline 3-Jan-2006 & Rokr E2 & Motorola & Entertainment \\
\hline 4-Jan-2006 & GW1 & $\begin{array}{l}\text { WNC Wistron } \\
\text { NeWeb } \\
\text { Corporation }\end{array}$ & $\begin{array}{l}\text { Advanced voice/data } \\
\text { communication }\end{array}$ \\
\hline 13-Feb-2006 & Hawk & E28 & Information management \\
\hline 13-Feb-2006 & Deamphone G500i & Grundig & $\begin{array}{l}\text { Traditional cellular } \\
\text { communication }\end{array}$ \\
\hline
\end{tabular}




\begin{tabular}{|c|c|c|c|}
\hline $\begin{array}{l}\text { Date of } \\
\text { announcement }\end{array}$ & Model & Manufacturer & Product type \\
\hline 14-Feb-2006 & E600 & Amoi Electronics & Information management \\
\hline 21-Feb-2006 & P901iTV & $\begin{array}{l}\text { Panasonic Mobile } \\
\text { Communications }\end{array}$ & Entertainment \\
\hline 8-Mar-2006 & Cosmex 8080 & Hagenuk & $\begin{array}{l}\text { Traditional cellular } \\
\text { communication }\end{array}$ \\
\hline 8-Mar-2006 & Cosmex 8090 & Hagenuk & Entertainment \\
\hline 10-Mar-2006 & I-SM1 & $\operatorname{ImCoSys}$ & $\begin{array}{l}\text { Traditional cellular } \\
\text { communication }\end{array}$ \\
\hline 14-Mar-2006 & A1200/Ming & Motorola & Information management \\
\hline 30-Mar-2006 & Eagle & E28 & Information management \\
\hline 30-Mar-2006 & Falcon & E28 & $\begin{array}{l}\text { Advanced voice/data } \\
\text { communication }\end{array}$ \\
\hline 30-Mar-2006 & Hercules & E28 & Entertainment \\
\hline 30-Mar-2006 & Phoenix & E28 & Information management \\
\hline 30-Mar-2006 & Rainbow & E28 & Information management \\
\hline 8-May-2006 & $\mathrm{SCH}-\mathrm{i} 819$ & $\begin{array}{l}\text { Samsung } \\
\text { Electronics }\end{array}$ & Information management \\
\hline 30-May-2006 & Twin & Neuf & $\begin{array}{l}\text { Traditional cellular } \\
\text { communication }\end{array}$ \\
\hline 5-Jun-2006 & P902iS & $\begin{array}{l}\text { Panasonic Mobile } \\
\text { Communications }\end{array}$ & Entertainment \\
\hline 1-Aug-2006 & SGH-i858 & $\begin{array}{l}\text { Samsung } \\
\text { Electronics }\end{array}$ & Information management \\
\hline 15-Aug-2006 & S101 & ROAD GmbH & Information management \\
\hline 15-Aug-2006 & S101K & ROAD GmbH & Information management \\
\hline 15-Aug-2006 & Greenphone & Trolltech & Information management \\
\hline 24-Aug-2006 & N902iX & NEC & Information management \\
\hline 3-Oct-2006 & V-Click & D-Link Systems, & Advanced voice/data \\
\hline
\end{tabular}




\begin{tabular}{|l|l|l|l|}
\hline $\begin{array}{l}\text { Date of } \\
\text { announcement }\end{array}$ & Model & Manufacturer & Product type \\
\hline & & Inc. & communication \\
\hline 7-Nov-2006 & Neo1973 & FIC & Information management \\
\hline 4-Dec-2006 & ROKR E6 & Motorola & Entertainment \\
\hline
\end{tabular}


Appendix 3: New adopters of mobile devices with Linux as the EOS

\begin{tabular}{|l|l|l|}
\hline Date of entry & Manufacturer & Manufacturer website \\
\hline 29-Nov-2000 & PalmPalm & www.palmpalm.com \\
\hline 3-Sep-2001 & Telepong Inc. & www.telepong.com \\
\hline 22-Jan-2003 & Consumer Direct Link, Inc. & www.cdlusa.com \\
\hline 14-Mar-2003 & Motorola & www.motorola.com \\
\hline 16-Dec-2003 & E28 & www.e28.com \\
\hline 16-Dec-2003 & Samsung Electronics & www.samsung.com \\
\hline 12-May-2004 & Curitel & www.curitel.com \\
\hline 9-Nov-2004 & Datang Mobile & www.datangmobile.cn \\
\hline 18-Nov-2004 & NEC & www.nec.com \\
\hline 1-Feb-2005 & Panasonic Mobile Communications & www.panasonicmobile.com \\
\hline 14-Feb-2005 & Cellon International & www.cellon.com \\
\hline 14-Mar-2005 & Haier & www.haier.com \\
\hline 5-Apr-2005 & Oswin Technology & www.oswintech.com \\
\hline 18-Apr-2005 & Yulong & www.yulong.com \\
\hline 1-Jun-2005 & Philips & www.philips.com \\
\hline 2-Jun-2005 & G-Tek Electronics & www.g-tekgroup.com \\
\hline 28-Jun-2005 & ZTE & www.zte.com.cn \\
\hline 6-Sep-2005 & TCL Mobile Communications & www.tclmobile.cn \\
\hline 4-Jan-2006 & WNC Wistron NeWeb Corporation & www.wneweb.com \\
\hline 13-Feb-2006 & Grundig & www.grundigmobile.de \\
\hline 14-Feb-2006 & Amoi Electronics & www.amoi.com \\
\hline 8-Mar-2006 & Hagenuk & www.hagenuk.de \\
\hline 10-Mar-2006 & ImCoSys & www.imcosys.com \\
\hline 30-May-2006 & Neuf & www.groupeneufcegetel.fr \\
\hline 15-Aug-2006 & ROAD GmbH & www.road-gmbh.de \\
\hline 15-Aug-2006 & Trolltech & www.trolltech.com \\
\hline 3-Oct-2006 & D-Link Systems, Inc. & www.dlink.com \\
\hline
\end{tabular}




\begin{tabular}{|l|l|l|}
\hline Date of entry & Manufacturer & Manufacturer website \\
\hline 7-Nov-2006 & FIC & www.fic.com.tw \\
\hline
\end{tabular}


Appendix 4: Relevant partnerships during the study period

\begin{tabular}{|c|c|c|c|}
\hline Date of partnership & Focal company & Partner(s) & $\begin{array}{l}\text { Type of } \\
\text { partner }\end{array}$ \\
\hline 12-Apr-2001 & PalmPalm & $\begin{array}{l}\text { Red Flag Software } \\
\text { Co., Ltd. }\end{array}$ & Supplier \\
\hline $20-\mathrm{Feb}-2002$ & PalmPalm & Intel & Supplier \\
\hline 17-Dec-2002 & Motorola & Embedix Inc. & Supplier \\
\hline 17-Mar-2003 & Curitel & Wildseed, Ltd. & Supplier \\
\hline 19-Mar-2003 & Motorola & Montavista & Supplier \\
\hline \multirow[t]{8}{*}{ 1-Jul-2003 } & NEC Corporation & CE Linux Forum & Consortium \\
\hline & & Samsung Electronics & Competitor \\
\hline & & $\begin{array}{l}\text { Panasonic Mobile } \\
\text { Communications }\end{array}$ & Competitor \\
\hline & & Sony Corporation & Competitor \\
\hline & & Hitachi Ltd. & Competitor \\
\hline & & $\begin{array}{l}\text { Royal Philips } \\
\text { Electronics }\end{array}$ & Competitor \\
\hline & & Sharp Corporation & Competitor \\
\hline & & Toshiba Corporation & Competitor \\
\hline 8-Jul-2003 & Motorola & Montavista & Supplier \\
\hline 11-Aug-2003 & Samsung Electronics & Montavista & Supplier \\
\hline $22-\mathrm{Oct}-2003$ & Motorola & RealNetworks, Inc. & Supplier \\
\hline 16-Dec-2003 & Motorola & CE Linux Forum & Consortium \\
\hline \multirow[t]{6}{*}{ 19-Dec-2003 } & Motorola & Fujitsu Limited & Competitor \\
\hline & & $\begin{array}{l}\text { Mitsubishi Electric } \\
\text { Corporation }\end{array}$ & Competitor \\
\hline & & NTT DoCoMo & $\begin{array}{l}\text { Service } \\
\text { provider }\end{array}$ \\
\hline & & NEC Corporation & Competitor \\
\hline & & $\begin{array}{l}\text { Panasonic Mobile } \\
\text { Communications }\end{array}$ & Competitor \\
\hline & & Sharp Corporation & Competitor \\
\hline 6-Feb-2004 & Motorola & Opera Software & Supplier \\
\hline 9-Mar-2004 & Motorola & $\begin{array}{l}\text { Belcarra Technologies } \\
\text { Corp. }\end{array}$ & Supplier \\
\hline 22-Apr-2004 & Motorola & \begin{tabular}{|l|} 
Picsel Technologies \\
\end{tabular} & Supplier \\
\hline 1-Nov-2004 & NEC Electronics & Montavista & Supplier \\
\hline 16-Nov-2004 & $\begin{array}{l}\text { Panasonic Mobile } \\
\text { Communications }\end{array}$ & Montavista & Supplier \\
\hline \multirow[t]{2}{*}{ 18-Nov-2004 } & NEC Corporation & NTT DoCoMo & $\begin{array}{l}\text { Service } \\
\text { provider }\end{array}$ \\
\hline & & $\begin{array}{l}\text { Panasonic Mobile } \\
\text { Communications }\end{array}$ & Competitor \\
\hline
\end{tabular}




\begin{tabular}{|c|c|c|c|}
\hline Date of partnership & Focal company & Partner(s) & $\begin{array}{l}\text { Type of } \\
\text { partner }\end{array}$ \\
\hline 22-Nov-2004 & NEC Electronics & NEC Corporation & Competitor \\
\hline 21-Jan-2005 & Vitelcom & Bouygues Telecom & $\begin{array}{l}\text { Service } \\
\text { provider }\end{array}$ \\
\hline 26-Jan-2005 & Vitelcom & Grundig & Competitor \\
\hline \multirow[t]{3}{*}{$11-$ Feb-2005 } & Samsung Electronics & Infeon Technologies & Supplier \\
\hline & & Trolltech & Supplier \\
\hline & & Emuzed & Supplier \\
\hline \multirow[t]{2}{*}{ 28-Feb-2005 } & NEC Corporation & NEC Soft, Ltd. & Supplier \\
\hline & & $\begin{array}{l}\text { NEC System } \\
\text { Technologies, Ltd. }\end{array}$ & Supplier \\
\hline 28-Jun-2005 & ZTE & Opera Software & Supplier \\
\hline 26-Jul-2005 & Motorola & Yahoo! Inc. & $\begin{array}{l}\text { Service } \\
\text { provider }\end{array}$ \\
\hline \multirow[t]{6}{*}{ 17-Oct-2005 } & Motorola & $\begin{array}{l}\text { Open Source } \\
\text { Development Lab } \\
\text { (OSDL) }\end{array}$ & Consortium \\
\hline & & $\begin{array}{l}\text { Mobile Linux } \\
\text { Initiative }\end{array}$ & Consortium \\
\hline & & Montavista & Supplier \\
\hline & & PalmSource, Inc. & Supplier \\
\hline & & Trolltech & Supplier \\
\hline & & $\begin{array}{l}\text { Wind River Systems } \\
\text { Inc. }\end{array}$ & Supplier \\
\hline \multirow[t]{11}{*}{ 14-Nov-2005 } & Cellon International & $\begin{array}{l}\text { Linux Phone } \\
\text { Standards Forum } \\
\text { (LiPS) }\end{array}$ & Consortium \\
\hline & & ARM Ltd. & Supplier \\
\hline & & Esmertec & Supplier \\
\hline & & France Telecom & $\begin{array}{l}\text { Service } \\
\text { provider }\end{array}$ \\
\hline & & $\begin{array}{l}\text { Finite State Machine } \\
\text { Labs, Inc. }\end{array}$ & Supplier \\
\hline & & Huawei & Competitor \\
\hline & & Jaluna & Supplier \\
\hline & & Mizi Research Inc. & Supplier \\
\hline & & Montavista & Supplier \\
\hline & & Open-Plug & Supplier \\
\hline & & PalmSource, Inc. & Supplier \\
\hline 6-Dec-2005 & $\mathrm{ZTE}$ & France Telecom & $\begin{array}{l}\text { Service } \\
\text { provider }\end{array}$ \\
\hline 6-Dec-2005 & Siemens AG & $\begin{array}{l}\text { Open Source } \\
\text { Development Labs } \\
\text { (OSDL) }\end{array}$ & Consortium \\
\hline
\end{tabular}




\begin{tabular}{|c|c|c|c|}
\hline Date of partnership & Focal company & Partner(s) & $\begin{array}{l}\text { Type of } \\
\text { partner }\end{array}$ \\
\hline 13-Feb-2006 & E28 & BridgePort Networks & Competitor \\
\hline 13-Feb-2006 & E28 & Boingo Wireless & $\begin{array}{l}\text { Service } \\
\text { provider }\end{array}$ \\
\hline 13-Feb-2006 & Motorola & BT & $\begin{array}{l}\text { Service } \\
\text { provider }\end{array}$ \\
\hline 8-May-2006 & Samsung Electronics & Mizi Research Inc. & Supplier \\
\hline \multirow[t]{5}{*}{ 15-Jun-2006 } & Motorola & NEC Corporation & Competitor \\
\hline & & NTT DoCoMo & $\begin{array}{l}\text { Service } \\
\text { provider }\end{array}$ \\
\hline & & $\begin{array}{l}\text { Panasonic Mobile } \\
\text { Communications }\end{array}$ & Competitor \\
\hline & & Samsung Electronics & Competitor \\
\hline & & Vodafone & $\begin{array}{l}\text { Service } \\
\text { provider }\end{array}$ \\
\hline 22-Jun-2006 & Motorola & Eclipse Foundation & Consortium \\
\hline \multirow[t]{3}{*}{ 17-Jul-2006 } & ZTE Corporation & $\begin{array}{l}\text { Linux Phone } \\
\text { Standards Forum } \\
\text { (LiPS) }\end{array}$ & Consortium \\
\hline & & Telecom Italia & $\begin{array}{l}\text { Service } \\
\text { provider }\end{array}$ \\
\hline & & Texas Instruments Inc. & Supplier \\
\hline 27-Jul-2006 & NEC Corporation & $\begin{array}{l}\text { Panasonic Mobile } \\
\text { Communications }\end{array}$ & Competitor \\
\hline 3-Oct-2006 & Motorola & France Telecom & $\begin{array}{l}\text { Service } \\
\text { provider }\end{array}$ \\
\hline 7-Nov-2006 & FIC & OpenMoko & Supplier \\
\hline $28-N o v-2006$ & NEC Electronics & Trolltech & Supplier \\
\hline 28-Nov-2006 & Datang Mobile & $\begin{array}{l}\text { Open Source } \\
\text { Development Labs } \\
\text { (OSDL) }\end{array}$ & Consortium \\
\hline
\end{tabular}


Appendix 5: Testing hypothesis 2 - Relation of new mobile devices entry rate and entry of new adopters entry rate per adoption stage

Correlation test

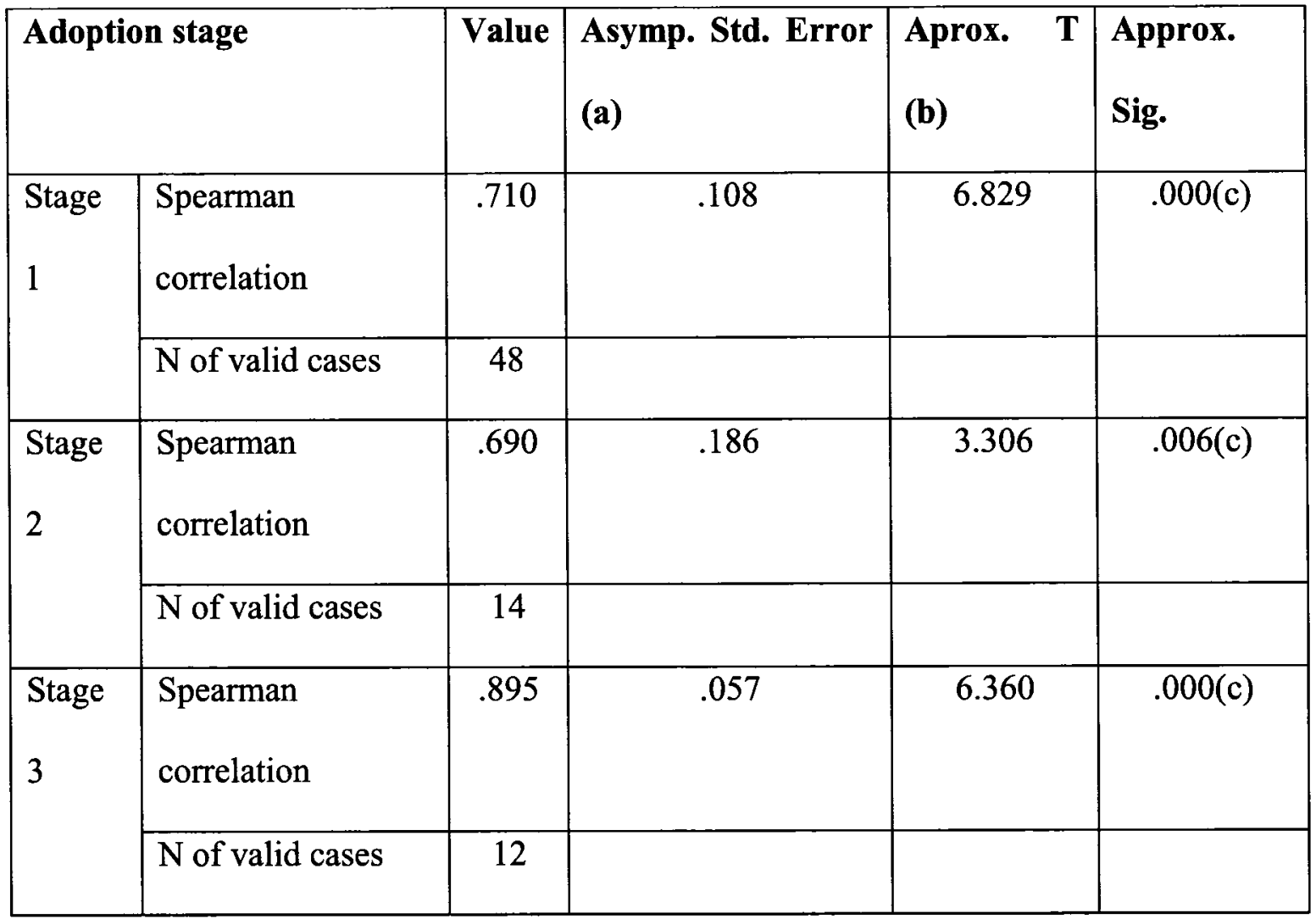

a. Not assuming the null hypothesis.

b. Using the asymptotic standard error assuming the null hypothesis.

c. Based on normal approximation. 
Appendix 6: Testing hypothesis 3a-Mann-Whitney $U$ test for type of product per adoption stage

Ranks

\begin{tabular}{|ll|r|r|r|}
\hline & Adoption stage & N & Mean Rank & Ranks \\
\hline Product type & Stage 1 & 12 & 15.88 & 190.50 \\
& Stage 2 & 19 & 16.08 & 305.50 \\
Total & 31 & & \\
\hline
\end{tabular}

Test Statistics(b)

\begin{tabular}{|l|r|}
\hline & Product type \\
\hline Mann-Whitney U & 112.500 \\
Wilcoxon W & 190.500 \\
$Z$ & -.065 \\
Asymp. Sig. (2- & .948 \\
tailed) & \\
Exact Sig. [2*(1- & $.952(a)$ \\
tailed Sig.)] & \\
\hline
\end{tabular}

a Not corrected for ties.

b Grouping Variable: Adoption stage 


\section{Ranks}

\begin{tabular}{|ll|r|r|c|}
\hline & Adoption stage & N & Mean Rank & Ranks \\
\hline Product type & Stage 1 & 12 & 18.88 & 226.50 \\
& Stage 3 & 26 & 19.79 & 514.50 \\
& Total & 38 & & \\
\hline
\end{tabular}

Test Statistics(b)

\begin{tabular}{|l|r|}
\hline & Product type \\
\hline Mann-Whitney U & 148.500 \\
Wilcoxon W & 226.500 \\
$\mathrm{Z}$ & -.264 \\
Asymp. Sig. (2- & .792 \\
tailed) & \\
Exact Sig. [2*(1- & $.816(\mathrm{a})$ \\
tailed Sig.)] & \\
\hline
\end{tabular}
a Not corrected for ties.
b Grouping Variable: Adoption stage 


\section{Ranks}

\begin{tabular}{|ll|r|r|r|}
\hline & Adoption stage & N & Mean Rank & $\begin{array}{c}\text { Sum of } \\
\text { Ranks }\end{array}$ \\
\hline Product type & Stage 2 & 19 & 22.34 & 424.50 \\
& Stage 3 & 26 & 23.48 & 610.50 \\
Total & 45 & & \\
\hline
\end{tabular}

Test Statistics(a)

\begin{tabular}{|l|r|}
\hline & Product type \\
\hline Mann-Whitney U & 234.500 \\
Wilcoxon W & 424.500 \\
Z & -.302 \\
Asymp. Sig. (2- & .763 \\
tailed) & \\
\hline
\end{tabular}

a Grouping Variable: Adoption stage 
Appendix 7: Testing hypothesis $3 b-$ Mann-Whitney $U$ test results for product diversity per adoption stage

Ranks

\begin{tabular}{|ll|r|r|r|}
\hline & $\begin{array}{l}\text { Stage of } \\
\text { adoption }\end{array}$ & N & \multicolumn{1}{c|}{$\begin{array}{c}\text { Mean } \\
\text { Rank }\end{array}$} & \multicolumn{1}{c|}{$\begin{array}{c}\text { Sum of } \\
\text { Ranks }\end{array}$} \\
\hline Product & Stage 1 & 48 & 25.73 & 1235.00 \\
diversity (per & Stage 2 & 14 & 51.29 & 718.00 \\
month) & Total & 62 & & \\
\hline
\end{tabular}

Test Statistics(a)

\begin{tabular}{|l|c|}
\hline & $\begin{array}{c}\text { Product } \\
\text { diversity } \\
\text { (per } \\
\text { month) }\end{array}$ \\
\hline Mann-Whitney U & 59.000 \\
Wilcoxon W & 1235.000 \\
Z & -4.722 \\
Asymp. Sig. (2- & .000 \\
tailed) & \\
\hline
\end{tabular}

a Grouping Variable: Stage of adoption 


\section{Ranks}

\begin{tabular}{|ll|r|r|r|}
\hline & $\begin{array}{l}\text { Stage of } \\
\text { adoption }\end{array}$ & N & Mean Rank & $\begin{array}{c}\text { Sum of } \\
\text { Ranks }\end{array}$ \\
\hline Product & Stage 1 & 48 & 24.50 & 1176.00 \\
diversity (per & Stage 3 & 12 & 54.50 & 654.00 \\
month) & Total & 60 & & \\
\hline
\end{tabular}

Test Statistics(a)

\begin{tabular}{|l|r|}
\hline & $\begin{array}{r}\text { Product } \\
\text { diversity } \\
\text { (per month) }\end{array}$ \\
\hline Mann-Whitney U & .000 \\
Wilcoxon W & 1176.000 \\
Z & -5.396 \\
Asymp. Sig. (2- & .000 \\
tailed) & \\
\hline
\end{tabular}

a Grouping Variable: Stage of adoption 


\section{Ranks}

\begin{tabular}{|ll|r|r|r|}
\hline & $\begin{array}{l}\text { Stage of } \\
\text { adoption }\end{array}$ & N & Mean Rank & $\begin{array}{c}\text { Rum of } \\
\text { Ranks }\end{array}$ \\
\hline Product & Stage 2 & 14 & 7.86 & 110.00 \\
diversity (per & Stage 3 & 12 & 20.08 & 241.00 \\
month) & Total & 26 & & \\
\hline
\end{tabular}

Test Statistics(b)

\begin{tabular}{|l|r|}
\hline & $\begin{array}{r}\text { Product } \\
\text { diversity } \\
\text { (per month) }\end{array}$ \\
\hline Mann-Whitney U & 5.000 \\
Wilcoxon W & 110.000 \\
Z & -4.074 \\
Asymp. Sig. (2- & .000 \\
tailed) & \\
Exact Sig. [2*(1- & $.000(a)$ \\
tailed Sig.)] & \\
\hline
\end{tabular}

a Not corrected for ties.

b Grouping Variable: Stage of adoption

Correlation test 
Appendix 8: Testing hypothesis 3d - Descriptive statistics for type of functions

featured per adoption stage

\begin{tabular}{|l|c|c|c|c|c|}
\hline Adoption stage & N (per stage) & Min & Max & Mean & Variance \\
\hline Stage 1 & & & & & \\
Traditional cellular communication & 101 & 1 & 14 & 8.42 & 18.992 \\
\hline Advanced voice/data communications & 65 & 1 & 7 & 5.42 & 3.538 \\
\hline Information management & 134 & 3 & 16 & 11.17 & 18.879 \\
\hline Entertainment & 81 & 0 & 15 & 6.75 & 22.568 \\
\hline Stage 2 & 144 & 2 & 15 & 7.58 & 19.702 \\
\hline Traditional cellular communication & 188 & 1 & 8 & 4.63 & 4.579 \\
\hline Advanced voice/data communications & 117 & 1 & 11 & 4.50 & 7.300 \\
\hline Information management & 134 & 1 & 18 & 7.05 & 18.608 \\
\hline Entertainment & & 0 & 18 & 6.96 & 33.158 \\
\hline Stage 3 & 117 & 0 & 17 & 5.65 & 27.515 \\
\hline Traditional cellular communication & & & & & \\
\hline Advanced voice/data communications & 117 & 12 & 5.79 & 11.398 \\
\hline Information management & & & & & \\
\hline
\end{tabular}




\begin{tabular}{|l|c|c|c|c|c|}
\hline Adoption stage & N (per stage) & Min & Max & Mean & Variance \\
\hline Total & & & & & \\
Cellular networking & 424 & 1 & 16 & 7.44 & 20.536 \\
\hline Advanced voice/data communications & 270 & 1 & 11 & 4.74 & 5.555 \\
\hline Information management & 425 & 0 & 18 & 7.46 & 26.181 \\
\hline Entertainment & 362 & 0 & 18 & 6.35 & 23.125 \\
\hline
\end{tabular}


Appendix 9: Testing hypothesis $4 \mathbf{c}$ - Relation of partnerships with competitors and industry consortia and entry of new mobile devices

\section{Correlations}

\begin{tabular}{|c|c|c|c|}
\hline \multirow{2}{*}{\multicolumn{2}{|c|}{ Spearman's rho }} & $\begin{array}{l}\text { New mobile } \\
\text { devices (per } \\
\text { month) }\end{array}$ & $\begin{array}{l}\text { Cumulative number of } \\
\text { partnerships with } \\
\text { competitors and } \\
\text { consortia for the } \\
\text { previous } 3 \text { months (per } \\
\text { month) }\end{array}$ \\
\hline & & & \\
\hline \multirow[t]{3}{*}{$\begin{array}{l}\text { New mobile devices (per } \\
\text { month) }\end{array}$} & $\begin{array}{l}\begin{array}{l}\text { Correlation } \\
\text { coefficient }\end{array} \\
\end{array}$ & 1.000 & $.342 * *$ \\
\hline & Sig. (2-tailed) & & .003 \\
\hline & $\mathrm{N}$ & 74 & 74 \\
\hline \multirow{3}{*}{$\begin{array}{l}\text { Cumulative number of } \\
\text { partnerships with } \\
\text { competitors and } \\
\text { consortia for the } \\
\text { previous } 3 \text { months (per } \\
\text { month) }\end{array}$} & $\begin{array}{l}\text { Correlation } \\
\text { coefficient }\end{array}$ & $.342 * *$ & 1.000 \\
\hline & Sig. (2-tailed) & .003 & \\
\hline & $\mathrm{N}$ & 74 & 74 \\
\hline
\end{tabular}

**. Correlation is significant at the 0.01 level (2-tailed) 